\title{
Characterization of Mexican Waste Biomass Relative to Energy Generation
}

José Guadalupe Rutiaga-Quiñones, ${ }^{\mathrm{a}, *}$ Luis Fernando Pintor-Ibarra, ${ }^{\mathrm{a}}$ Rocio OrihuelaEquihua, ${ }^{\mathrm{a}}$ Nicolás González-Ortega, ${ }^{\mathrm{a}}$ María Alejandra Ramírez-Ramírez, ${ }^{\mathrm{a}}$ Artemio Carrillo-Parra, ${ }^{\mathrm{b}}$ Noel Carrillo-Ávila, ${ }^{\mathrm{c}}$ Manuel Alfonso Navarrete-García, ${ }^{\mathrm{d}}$ Faustino RuízAquino, ${ }^{\mathrm{e}}$ José René Rangel-Méndez, ${ }^{\mathrm{f}}$ Juan José Hernández-Solís, ${ }^{\mathrm{g}}$ and Concepción Luján-Álvarez ${ }^{\mathrm{h}}$

In this work, physical and chemical analyses of 28 sawdust samples (tropical woods, pine woods, and oak woods) derived from the primary process of wood transformation and 4 samples of citrus residues were performed, as an option to make densified biofuels. The study included the determination of initial moisture, particle size distribution, proximate analysis, ultimate analysis, calculation of the calorific value, and ash microanalysis. The initial moisture content of the biomass samples ranged from 6.04 to $75.21 \%$. The biomass granulometry results indicate that the highest proportion corresponds to the 1.0-mm (33.10\%) (Fraction retained in mesh $0.5 \mathrm{~mm})$. Other results obtained indicate the following ranges: ash content $(0.27$ to $6.27 \%)$, volatile matter $(78.90$ to $90.50 \%)$, fixed carbon ( 9.10 to $20.44 \%$ ), carbon ( 49.13 to $50.78 \%$ ), oxygen (42.62 to $44.49 \%$ ), and hydrogen (5.24 to $6.55 \%)$. The calculated calorific value ranged from $17.65 \mathrm{MJ} / \mathrm{kg}$ to $20.72 \mathrm{MJ} / \mathrm{kg}$. The chemical elements with the highest concentration in the biomass samples were $\mathrm{K}$ and $\mathrm{Ca}$, followed in some cases by $\mathrm{Al}$ and $\mathrm{P}$. The biomass with the greatest possibilities for making densified biofuels of better quality is the group of pine woods because they have low mineral content, low nitrogen content, and high calorific value.

Keywords: Lignocellulosic residues; Bioenergy; Calorific value; Chemical analysis

Contact information: a: Facultad de Ingeniería en Tecnología de la Madera, Edificio "D”, Ciudad Universitaria, Universidad Michoacana de San Nicolás de Hidalgo, Av. Fco. J. Múgica S/N, Col. Felicitas del Rio, Morelia, Michoacán, C. P. 58040, México; b: Instituto de Silvicultura e Industria de la Madera, Universidad Juárez del Estado de Durango, Boulevard del Guadiana No. 501, Ciudad Universitaria, Durango, Durango, C. P. 34120 México; c: Insituto de Investigaciones Forestales, Agrícolas y Pecuarias, San Martinito, Km 56.5 Carretera Federal México-Puebla, San Martinito, Municipio de Tlahuapan, Puebla, C. P. 74100 México; d: Cítricos EX, S.A. de C.V., Carretera a Cañadas s/n, Col. Los Puentes, Martínez de la Torre, Veracruz, C. P. 93600 México; e: Instituto de Estudios Ambientales, Universidad de la Sierra Juárez, Avenida Universidad S/N, Ixtlán de Juárez, Oaxaca, C.P. 68725 México; f: Instituto Potosino de Investigación Científica y Tecnológica, A. C., División de Ciencias Ambientales, Camino a la Presa de San José 2055, Col. Lomas 4a Sección, San Luis Potosí, S. L. P., C. P. 78216 México; g: Tecnológico Nacional de México - Campus Instituto Tecnológico de la Zona Maya, Carretera ChetumalEscárcega Km 21.5, Ejido Juan Sarabia, Quintana Roo, C. P. 77695 México; h: Facultad de Ciencias Agrícolas y Forestales, Universidad Autónoma de Chihuahua, Carretera Km 2.5 Delicias-Rosales, Cd. Delicias, Chihuahua, C. P. 33000 México; *Corresponding author: rutiaga@umich.mx

\section{INTRODUCTION}

It is known that currently the primary source of energy in the world is based on fossil fuels. This strong dependence has had harmful effects both on the environment and society itself, reducing energy security and producing high emissions of greenhouse gases 
and other pollutants from the combustion process of coal, natural gas, and petroleum derivatives (García et al. 2016). The effect on climate change from the use of these fossil fuels and perhaps the decrease in oil reserves has encouraged the demand for energy from renewable sources worldwide (Escorsim et al. 2018). Mexico depends on fossil fuels to satisfy its energy needs, where oil represents $62.4 \%$, followed by natural gas with $19.7 \%$, and coal with $4.3 \%$ of total demand (SENER 2019). This indicates that Mexico has a long way to go in its transition to renewable sources (García et al. 2016), even having the advantage of its great potential of biomass resources to produce solid biofuels, liquid biofuels, and biogas (REMBIO 2011).

The share of renewable energies in Mexico is $10.4 \%$ and is distributed as follows: $1.5 \%$ for hydroenergy, $5.7 \%$ biomass (firewood and sugarcane bagasse), $2.8 \%$ geoenergy (including solar and wind), and $0.1 \%$ biogas (SENER 2019). The primary sources of biomass supply include native forests and jungles and plantations or crops for energy. The secondary sources of biomass are those derived from the processes of wood use and industrialization, agricultural crops, and agro-industrial waste (Tauro et al. 2016). Mexico's forest vegetation comprises of 138 million hectares, which is equivalent to $70 \%$ of the national territory, while its forests and rain forests comprise 64.9 million hectares, of which 15 million hectares can be used for forestry (CONAFOR 2017). It has been estimated that the technical potential of bioenergy in Mexico is equivalent to 3,569 $\mathrm{PJ} / \mathrm{yr}$ or $42 \%$ of primary energy consumption in 2008; wood represents $54 \%$ of the total potential with 1,923 PJ annually, of which 1,515 PJ/yr come from the management of native forests, while $345 \mathrm{PJ} / \mathrm{yr}$ could be obtained by establishing 2.9 million hectares of forest plantations with eucalyptus (REMBIO 2011). The use of wood for bioenergetic purposes could stimulate forest production for industrial uses through the commercialization of residues and less or less valued species (Tauro et al. 2016).

Due to its abundance, wood as a lignocellulosic material has been used throughout history not only as a construction material, but also in the manufacturing of furniture, plywood, particleboard, in coal production, in the pulp and paper industry, and with other chemicals derived from their heat or chemical treatment (Fengel and Wegener 1983). Recently a study examined bio-based rigid polyurethane foam compounds made from apricot kernel shells, which are precisely lignocellulosic residues (Fidan and Ertaş 2020). Wood-processing industries generate a large amount of waste (sawdust, bark, shavings, chips, and slabs) that usually have no further use (Zavala and Cortés 2000), which makes biomass an economically competitive source of energy with fossil fuels (García et al. 2012). Furthermore, the use of wood as energy is of little value, so the focus should be on the use of wood waste and forest residues (Karinkanta et al. 2018). Thus, in a favorable medium-term scenario (2025 to 2030), with the obligation of the industry to use clean energy, an increase in the demand for sawdust, chips, bark, and other bio-waste is expected (Arias-Chalico 2018).

Solid biofuels, including firewood, wood chips, pellets, briquettes, and charcoal, are considered important energy vectors derived from biomass (Riegelhaupt 2016). Previous studies of different biomasses indicate wide variation in their composition (Werkelin et al. 2005; Spinelli et al. 2011), so it is necessary to evaluate the characteristics and properties of these biofuels and other derivatives of wood industrialization, for domestic or industrial uses (Mitchual et al. 2014). In this sense, the objective of the present study was the physical and chemical evaluation of sawdust from coniferous woods and hardwoods, derived from the primary processing of wood, as well as from lemon peel residues from a fruit processing plant and citrus residues (branches and leaves) coming 
from pruning activities in orchards. The goal was to determine the feasibility of using them for the production of densified biofuels and also to generate reference data for comparison with other samples of biomass biofuels.

\section{EXPERIMENTAL}

\section{Materials}

The biomass samples for this study include sawdust from hardwoods and softwoods, as well as citrus residues; these materials were collected in eight states (Quintana Roo, Chihuahua, Michoacán, Durango, Oaxaca, Veracruz, Nuevo León, and Sonora) of the Mexican Republic. Sawdust samples come from the primary transformation process of the wood from different logging industries (in Quintana Roo: Ejido Noh-Bec, Ejido Petcacab, and Ejido Tres Garantías; in Chihuahua: Ejido El largo, Ejido Agua azul, Grupo Gazo, and Multimaderas; in Michoacán: Maderería Zamora, Maderas Preciosas Don Jesús, and Ejido Lázaro Cárdenas; in Durango: Grupo Sezarik, Maderas y Tarimas Alba, Ejido Vencedores, Ejido La Cañita, and Ejido Pueblo Nuevo; in Oaxaca: Unidad Comunal Forestal, Agropecuaria y de Servicios, Productora Comunal de Muebles Ixtlán, and Aserradero Mapsi; and in Sonora: Artesanías Don Lupe), the lemon peel from a fruit processing plant (Grupo Altex, in Veracruz), and the citrus residues (branches and leaves) come from pruning activities in the orchards (Martínez de la Torre, Veracruz).

\section{Moisture Content}

The initial moisture content of each material was determined immediately after its collection as per UNE-EN 14774-1 (2010). For citrus residues (branches), it was necessary to reduce their size to make this determination. Later, all the materials were left to dry in the open air in the shade, because later a chemical analysis of this biomass will also be carried out.

\section{Granulometry}

Subsequently, the particle size of each material was determined as per UNE-EN 15149-2 (2011), except for citrus residues. Only a fraction of the collected biomass was ground and sieved, and the 40-mesh fraction was used to determine proximate analysis and ultimate analysis.

\section{Proximate Analysis}

The ash content as per UNE-EN 14775 (2010) and the volatile matter as per ASTM E872-82 (2013) were determined. For this case, absolutely dry 40 mesh biomass was used. Fixed carbon was calculated by difference, subtracting the ash content and the volatile content from 100 (García et al. 2012).

\section{Ultimate Analysis}

The content of carbon, hydrogen, nitrogen, and sulfur was measured in a Costech brand elemental analyzer (Model 4010; Costech International S.p.A., Milan, Italy) as per UNE-CEN/TS 15104 EX (2008). For this case, absolutely dry 40 mesh biomass was used. Oxygen content was calculated by difference (Ghetti et al. 1996). 


\section{High Heating Value Calculation}

For the calculation of the calorific value for various lignocellulosic materials, numerous investigations on mathematical models have been published. For this case and based on the chemical analyses developed here, prediction models based on elemental analysis $(\mathrm{HHV}=0.335 \mathrm{C}+1.423 \mathrm{H}-0.154 \mathrm{O}-0.145 \mathrm{~N} ; \mathrm{C}=$ carbon, $\mathrm{H}=$ hydrogen, $\mathrm{O}=$ oxygen, $\mathrm{N}=$ nitrogen) (Demirbaş 1997), to the proximate analysis $(\mathrm{HHV}=0.3543 \mathrm{FC}+$ $0.1708 \mathrm{VM} ; \mathrm{FC}=$ fixed carbon, $\mathrm{VM}=$ volatile material) (Cordero et al. 2001 ), and to the ash content $(\mathrm{HHV}=19.914-0.2324 \mathrm{~A} ; \mathrm{A}=$ ashes) (Sheng and Azevedo 2005) were used.

\section{Ash Microanalysis}

Microanalysis of the ashes was determined by inductively coupled plasma atomic emission spectrophotometer (ICP-AES) in a Varian spectrometer (Model 730-ES; Varian Inc. (Agilent), Mulgrave, Australia) (Arcibar-Orozco et al. 2014).

\section{Statistic Analysis}

Initial moisture, granulometry, and proximate analysis were performed three times and the results illustrated the average and standard deviation. Results obtained by means of instrumental analysis (ultimate analysis and ash microanalysis) only report the value obtained. The authors did not use any software to calculate the averages and standard deviations.

\section{RESULTS AND DISCUSSION}

\section{Moisture Content}

Table 1 summarizes the total of the samples, and they appear in the order of collection, the place of origin, if any, name of the species, and initial moisture content. The humidity of the biomass to make densified biofuels is an important factor (Obernberger and Thek 2010) and influences the properties of these materials (Núñez-Retana et al. 2019). The initial moisture content of the biomass samples ranged from $6.0 \%$ to $75.2 \%$. This difference is due to the fact that sometimes at the time of collection it was just processing green wood and on other occasions it was material already stored outdoors. In the case of the pine sawdust samples, the moisture content ranged from $6.6 \%$ to $75.2 \%$, while the moisture of the hardwoods ranged from $6.0 \%$ to $52.4 \%$. The citrus residues had an initial moisture of $19.2 \%$ to $70.9 \%$. A recent study reports $3.1 \%$ moisture content for apricot stone shell (Fidan and Ertaş 2020).

According to the results obtained here, it can be said that in general the initial moisture content of lignocellulosic materials is within the initial values found for pine woods (Correa-Méndez et al. 2014; Pintor-Ibarra et al. 2017) or for biomass in general (Vassilev et al. 2010; Velázquez 2018).

To use this biomass for the production of densified biofuels, it would be necessary to adjust the moisture content by means of some drying process and achieve the adequate humidity, because to make pellets the material must be no more than $10 \%$ (Obernberger and Thek 2010) and to make briquettes the maximum humidity must be $18 \%$ (ÖNORM $71352000)$. 
Table 1. Origin, Name, and Humidity of the Biomass Samples

\begin{tabular}{|c|c|c|c|}
\hline Sample & Origin & Name & $\begin{array}{c}\text { Moisture Initial } \\
(\%)\end{array}$ \\
\hline 1 & \multirow{6}{*}{ Quintana Roo } & Swartzia cubensis & $35.58 \pm 0.23$ \\
\hline 2 & & Lysiloma latisiliquum & $52.38 \pm 0.46$ \\
\hline 3 & & Caesalpinia platyloba & $47.68 \pm 0.06$ \\
\hline 4 & & Manilkara zapota & $44.13 \pm 0.21$ \\
\hline 5 & & Swartzia cubensis & $25.11 \pm 0.26$ \\
\hline 6 & & Swietenia macrophylla & $25.83 \pm 0.31$ \\
\hline 7 & \multirow{4}{*}{ Chihuahua } & Pinus spp. & $49.15 \pm 0.63$ \\
\hline 8 & & Pinus spp. & $37.40 \pm 0.14$ \\
\hline 9 & & Pinus spp. & $54.40 \pm 0.35$ \\
\hline 10 & & Pinus spp. & $54.44 \pm 0.25$ \\
\hline 11 & \multirow{5}{*}{ Michoacán } & Pinus spp. & $31.23 \pm 0.58$ \\
\hline 12 & & Pinus spp. & $12.27 \pm 0.55$ \\
\hline 13 & & Pinus spp. & $8.57 \pm 0.58$ \\
\hline 14 & & Pinus spp. & $6.60 \pm 0.57$ \\
\hline 15 & & Pinus spp. & $46.58 \pm 1.35$ \\
\hline 16 & \multirow{8}{*}{ Durango } & Pinus spp. & $39.74 \pm 0.45$ \\
\hline 17 & & Pinus spp. & $6.70 \pm 0.15$ \\
\hline 18 & & Pinus spp. & $43.12 \pm 0.75$ \\
\hline 19 & & Quercus spp. & $46.30 \pm 0.18$ \\
\hline 20 & & Pinus spp. & $63.46 \pm 0.40$ \\
\hline 21 & & Pinus spp. & $56.40 \pm 0.79$ \\
\hline 22 & & Quercus spp. & $33.59 \pm 0.66$ \\
\hline 23 & & Pinus spp. & $32.67 \pm 0.36$ \\
\hline 24 & \multirow{3}{*}{ Oaxaca } & Pinus spp. & $41.93 \pm 0.20$ \\
\hline 25 & & Pinus spp. & $8.50 \pm 0.18$ \\
\hline 26 & & Pinus spp. & $75.21 \pm 0.38$ \\
\hline 27 & \multirow{4}{*}{ Veracruz } & Persian lime branches & $41.76 \pm 0.24$ \\
\hline 28 & & Persian lime leaves & $70.89 \pm 0.52$ \\
\hline 29 & & Orange branches & $29.05 \pm 0.65$ \\
\hline 30 & & Lemon peels & $19.23 \pm 0.78$ \\
\hline 31 & Nuevo León & Pinus spp. & $12.16 \pm 0.37$ \\
\hline 32 & Sonora & Olneya tesota & $6.04 \pm 0.22$ \\
\hline
\end{tabular}

\section{Granulometry}

The particle size of the collected biomass samples appears in Table 2, except for citrus residues (samples 27 through 30). The particle size that is generated in the primary processing of wood depends on the wood, the type of saws (band or circular saws) that are used, the cutting speed and feeding speed, and the number and characteristics of the teeth of the mountains and their edge. In this work, the characteristics of the cutting tools used to process the wood were not followed up; however, the particle size obtained corresponds to the typical size of sawdust (1 to $5 \mathrm{~mm}$ ) (Obernberger and Thek 2010; UNE-EN 1496112011 ) and is considered optimal for making pellets (Ortíz et al. 2003; Obernberger and Thek 2010). The biomass granulometry results indicated that the highest proportion corresponds to the $1.0-\mathrm{mm}(33.10 \%)$ (retained fraction in mesh $0.5 \mathrm{~mm}$ ), followed by the $0.5-\mathrm{mm}(19.65 \%)$ (retained fraction in mesh $0.25 \mathrm{~mm}$ ), and the 1.4-mm $(13.16 \%)$ (retained fraction in mesh $1.0 \mathrm{~mm}$ ), and in a smaller proportion corresponded to the mesh at 3.15 $\mathrm{mm}(3.20 \%)$ (retained fraction in mesh $2.8 \mathrm{~mm}$ ) and greater than $3.15 \mathrm{~mm}(3.64 \%)$ (retained fraction in mesh $3.15 \mathrm{~mm}$ ). In contrast, it is known that particles from 0.60 to $0.80 \mathrm{~mm}$ produce good quality pellets (Turner 1995) and a recent study used a particle size 
less than $4 \mathrm{~mm}$ obtaining pellets with acceptable physical and mechanical characteristics (Carrillo-Parra et al. 2018). Other studies suggest mixtures of different particle sizes with good results on pellet properties (MacBain 1966; Payne 1978; Grover and Mishra 1996). Based to the results obtained, the biomass studied can be used to make densified biofuels.

Table 2. Particle Size Distribution of Sawdust Samples (\%)

\begin{tabular}{|c|c|c|c|c|c|c|c|c|}
\hline $\begin{array}{l}\text { Mesh } \\
(\mathrm{mm})\end{array}$ & 3.15 & 2.8 & 2.0 & 1.4 & 1.0 & 0.5 & 0.25 & Tray \\
\hline $\begin{array}{c}\text { Retained } \\
\text { fraction } \\
(\mathrm{mm})\end{array}$ & $>3.15$ & 3.15 & 2.8 & 2.0 & 1.4 & 1.0 & 0.5 & $\leq 0.25$ \\
\hline Sample & \multicolumn{8}{|c|}{ Quintana Roo } \\
\hline 1 & $\begin{array}{c}1.15 \\
\pm 0.30\end{array}$ & $\begin{array}{l}0.48 \\
\pm 0.5\end{array}$ & $\begin{array}{c}2.69 \\
\pm 0.28\end{array}$ & $\begin{array}{c}7.92 \\
\pm 0.37\end{array}$ & $\begin{array}{l}13.43 \\
\pm 0.49\end{array}$ & $\begin{array}{l}43.82 \\
\pm 0.83\end{array}$ & $\begin{array}{l}22.50 \\
\pm 0.78\end{array}$ & $\begin{array}{c}8.01 \\
\pm 0.87\end{array}$ \\
\hline 2 & $\begin{array}{c}1.31 \\
\pm 0.71\end{array}$ & $\begin{array}{c}0.46 \\
\pm 0.15\end{array}$ & $\begin{array}{c}1.42 \\
\pm 0.33\end{array}$ & $\begin{array}{c}5.07 \\
\pm 0.88\end{array}$ & $\begin{array}{l}11.21 \\
\pm 0.97\end{array}$ & $\begin{array}{l}42.81 \\
\pm 1.51\end{array}$ & $\begin{array}{l}26.91 \\
\pm 1.84\end{array}$ & $\begin{array}{l}10.80 \\
\pm 2.42\end{array}$ \\
\hline 3 & $\begin{array}{c}7.11 \\
\pm 1.55\end{array}$ & $\begin{array}{c}1.84 \\
\pm 0.07\end{array}$ & $\begin{array}{c}2.29 \\
\pm 0.18\end{array}$ & $\begin{array}{c}3.29 \\
\pm 0.13\end{array}$ & $\begin{array}{c}8.64 \\
\pm 0.42\end{array}$ & $\begin{array}{l}45.29 \\
\pm 0.85\end{array}$ & $\begin{array}{l}28.35 \\
\pm 0.65\end{array}$ & $\begin{array}{c}3.19 \\
\pm 0.11\end{array}$ \\
\hline 4 & $\begin{array}{c}2.07 \\
\pm 1.43 \\
\end{array}$ & $\begin{array}{c}0.42 \\
\pm 0.16 \\
\end{array}$ & $\begin{array}{c}1.03 \\
\pm 0.19 \\
\end{array}$ & $\begin{array}{c}2.78 \\
\pm 0.41 \\
\end{array}$ & $\begin{array}{c}7.64 \\
\pm 0.80 \\
\end{array}$ & $\begin{array}{l}38.81 \\
\pm 1.15 \\
\end{array}$ & $\begin{array}{l}31.63 \\
\pm 0.85 \\
\end{array}$ & $\begin{array}{r}15.62 \\
\pm 1.22 \\
\end{array}$ \\
\hline 5 & $\begin{array}{c}2.77 \\
\pm 0.37\end{array}$ & $\begin{array}{c}2.98 \\
\pm 0.08\end{array}$ & $\begin{array}{c}4.39 \\
\pm 0.33\end{array}$ & $\begin{array}{c}6.88 \\
\pm 0.41\end{array}$ & $\begin{array}{l}13.04 \\
\pm 0.40\end{array}$ & $\begin{array}{l}40.61 \\
\pm 0.19\end{array}$ & $\begin{array}{l}19.67 \\
\pm 0.47\end{array}$ & $\begin{array}{c}9.66 \\
\pm 0.29\end{array}$ \\
\hline 6 & $\begin{array}{c}0.72 \\
\pm 0.23 \\
\end{array}$ & $\begin{array}{c}0.35 \\
\pm 0.11 \\
\end{array}$ & $\begin{array}{c}0.82 \\
\pm 0.06 \\
\end{array}$ & $\begin{array}{c}3.09 \\
\pm 0.39\end{array}$ & $\begin{array}{c}7.44 \\
\pm 0.49 \\
\end{array}$ & $\begin{array}{l}33.77 \\
\pm 1.25 \\
\end{array}$ & $\begin{array}{l}31.01 \\
\pm 0.47 \\
\end{array}$ & $\begin{array}{l}22.80 \\
\pm 1.48 \\
\end{array}$ \\
\hline \multicolumn{9}{|c|}{ Chihuahua } \\
\hline 7 & $\begin{array}{c}0.11 \\
\pm 0.05\end{array}$ & $\begin{array}{c}0.03 \\
\pm 0.02\end{array}$ & $\begin{array}{c}0.19 \\
\pm 0.04\end{array}$ & $\begin{array}{c}1.25 \\
\pm 0.17\end{array}$ & $\begin{array}{c}5.47 \\
\pm 0.45\end{array}$ & $\begin{array}{l}39.08 \\
\pm 0.90\end{array}$ & $\begin{array}{l}35.97 \\
\pm 0.75\end{array}$ & $\begin{array}{l}17.90 \\
\pm 0.79\end{array}$ \\
\hline 8 & $\begin{array}{c}2.23 \\
\pm 0.49\end{array}$ & $\begin{array}{c}0.55 \\
\pm 0.06\end{array}$ & $\begin{array}{c}0.97 \\
\pm 0.18\end{array}$ & $\begin{array}{c}1.52 \\
\pm 0.19\end{array}$ & $\begin{array}{c}3.93 \\
\pm 0.43\end{array}$ & $\begin{array}{l}31.19 \\
\pm 0.93\end{array}$ & $\begin{array}{l}37.31 \\
\pm 0.42\end{array}$ & $\begin{array}{l}22.30 \\
\pm 1.43\end{array}$ \\
\hline 9 & $\begin{array}{c}1.04 \\
\pm 0.22\end{array}$ & $\begin{array}{c}0.37 \\
\pm 0.02\end{array}$ & $\begin{array}{c}0.72 \\
\pm 0.12\end{array}$ & $\begin{array}{c}2.68 \\
\pm 0.10\end{array}$ & $\begin{array}{l}10.11 \\
\pm 0.42\end{array}$ & $\begin{array}{l}47.12 \\
\pm 0.97\end{array}$ & $\begin{array}{l}29.77 \\
\pm 0.78\end{array}$ & $\begin{array}{c}8.20 \\
\pm 0.63\end{array}$ \\
\hline 10 & $\begin{array}{c}1.21 \\
\pm 0.54\end{array}$ & $\begin{array}{c}1.35 \\
\pm 0.15\end{array}$ & $\begin{array}{c}9.18 \\
\pm 1.14\end{array}$ & $\begin{array}{l}33.18 \\
\pm 1.07 \\
\end{array}$ & $\begin{array}{l}24.50 \\
\pm 1.08 \\
\end{array}$ & $\begin{array}{l}22.56 \\
\pm 0.83 \\
\end{array}$ & $\begin{array}{c}5.89 \\
\pm 0.76 \\
\end{array}$ & $\begin{array}{c}2.13 \\
\pm 0.21\end{array}$ \\
\hline \multicolumn{9}{|c|}{ Michoacán } \\
\hline 11 & $\begin{array}{c}2.28 \\
\pm 0.64 \\
\end{array}$ & $\begin{array}{c}1.26 \\
\pm 0.20 \\
\end{array}$ & $\begin{array}{c}2.98 \\
\pm 0.14\end{array}$ & $\begin{array}{r}10.56 \\
\pm 0.35 \\
\end{array}$ & $\begin{array}{r}18.93 \\
\pm 0.25 \\
\end{array}$ & $\begin{array}{l}40.81 \\
\pm 0.77 \\
\end{array}$ & $\begin{array}{r}17.22 \\
\pm 0.28 \\
\end{array}$ & $\begin{array}{c}5.94 \\
\pm 0.14 \\
\end{array}$ \\
\hline 12 & $\begin{array}{c}2.72 \\
\pm 1.01\end{array}$ & $\begin{array}{c}4.48 \\
\pm 0.34\end{array}$ & $\begin{array}{l}11.31 \\
\pm 0.71\end{array}$ & $\begin{array}{l}18.59 \\
\pm 0.85\end{array}$ & $\begin{array}{l}19.90 \\
\pm 0.44\end{array}$ & $\begin{array}{l}25.80 \\
\pm 0.89\end{array}$ & $\begin{array}{l}12.29 \\
\pm 1.20\end{array}$ & $\begin{array}{c}6.91 \\
\pm 0.59\end{array}$ \\
\hline 13 & $\begin{array}{c}4.42 \\
\pm 0.68 \\
\end{array}$ & $\begin{array}{c}1.66 \\
\pm 0.22 \\
\end{array}$ & $\begin{array}{r}1.59 \\
\pm 0.89 \\
\end{array}$ & $\begin{array}{c}4.91 \\
\pm 0.24 \\
\end{array}$ & $\begin{array}{c}8.51 \\
\pm 0.22 \\
\end{array}$ & $\begin{array}{r}34.85 \\
\pm 0.70 \\
\end{array}$ & $\begin{array}{l}28.35 \\
\pm 0.35\end{array}$ & $\begin{array}{l}15.71 \\
\pm 0.63\end{array}$ \\
\hline 14 & $\begin{array}{l}10.42 \\
\pm 1.05\end{array}$ & $\begin{array}{c}6.25 \\
\pm 0.42\end{array}$ & $\begin{array}{l}16.74 \\
\pm 0.43\end{array}$ & $\begin{array}{l}25.30 \\
\pm 0.33\end{array}$ & $\begin{array}{r}15.88 \\
\pm 0.48\end{array}$ & $\begin{array}{l}17.31 \\
\pm 0.83\end{array}$ & $\begin{array}{c}5.65 \\
\pm 0.42\end{array}$ & $\begin{array}{c}2.46 \\
\pm 0.15\end{array}$ \\
\hline 15 & $\begin{array}{c}1.22 \\
\pm 0.82 \\
\end{array}$ & $\begin{array}{c}1.05 \\
\pm 0.31 \\
\end{array}$ & $\begin{array}{c}3.77 \\
\pm 0.41 \\
\end{array}$ & $\begin{array}{r}11.35 \\
\pm 0.83 \\
\end{array}$ & $\begin{array}{r}18.96 \\
\pm 0.63 \\
\end{array}$ & $\begin{array}{r}42.47 \\
\pm 1.43 \\
\end{array}$ & $\begin{array}{r}17.06 \\
\pm 0.24 \\
\end{array}$ & $\begin{array}{c}4.11 \\
\pm 1.36 \\
\end{array}$ \\
\hline \multicolumn{9}{|c|}{ Durango } \\
\hline 16 & $\begin{array}{c}2.07 \\
\pm 0.35\end{array}$ & $\begin{array}{c}3.33 \\
\pm 0.22\end{array}$ & $\begin{array}{l}14.61 \\
\pm 0.12\end{array}$ & $\begin{array}{l}31.97 \\
\pm 0.65\end{array}$ & $\begin{array}{l}19.87 \\
\pm 0.04\end{array}$ & $\begin{array}{l}21.17 \\
\pm 0.63\end{array}$ & $\begin{array}{c}5.13 \\
\pm 0.39\end{array}$ & $\begin{array}{c}1.84 \\
\pm 0.06\end{array}$ \\
\hline 17 & $\begin{array}{c}2.68 \\
\pm 0.73\end{array}$ & $\begin{array}{c}2.28 \\
\pm 0.14\end{array}$ & $\begin{array}{l}5.52 \\
\pm 0.21\end{array}$ & $\begin{array}{l}10.65 \\
\pm 0.20\end{array}$ & $\begin{array}{l}12.02 \\
\pm 0.05\end{array}$ & $\begin{array}{l}24.74 \\
\pm 0.15\end{array}$ & $\begin{array}{l}19.94 \\
\pm 0.53\end{array}$ & $\begin{array}{l}22.17 \\
\pm 0.59\end{array}$ \\
\hline 18 & $\begin{array}{l}19.30 \\
\pm 2.06\end{array}$ & $\begin{array}{l}20.94 \\
\pm 0.68\end{array}$ & $\begin{array}{l}27.54 \\
\pm 0.78 \\
\end{array}$ & $\begin{array}{l}18.61 \\
\pm 0.60\end{array}$ & $\begin{array}{c}6.36 \\
\pm 0.46 \\
\end{array}$ & $\begin{array}{c}4.42 \\
\pm 1.09 \\
\end{array}$ & $\begin{array}{c}1.67 \\
\pm 0.55 \\
\end{array}$ & $\begin{array}{c}1.16 \\
\pm 0.19\end{array}$ \\
\hline 19 & $\begin{array}{c}1.48 \\
\pm 0.71\end{array}$ & $\begin{array}{c}1.31 \\
\pm 0.47\end{array}$ & $\begin{array}{c}3.67 \\
\pm 0.64\end{array}$ & $\begin{array}{l}10.74 \\
\pm 1.35\end{array}$ & $\begin{array}{l}16.42 \\
\pm 1.30\end{array}$ & $\begin{array}{l}36.89 \\
\pm 0.27\end{array}$ & $\begin{array}{l}19.97 \\
\pm 2.16\end{array}$ & $\begin{array}{c}9.53 \\
\pm 2.41\end{array}$ \\
\hline 20 & 0.42 & 0.35 & 2.07 & 11.46 & 20.68 & 48.88 & 13.77 & 2.37 \\
\hline
\end{tabular}




\begin{tabular}{|c|c|c|c|c|c|c|c|c|}
\hline & \pm 0.16 & \pm 0.07 & \pm 0.09 & \pm 0.70 & \pm 0.86 & \pm 0.65 & \pm 0.83 & \pm 0.33 \\
\hline \multirow{2}{*}{21} & 4.42 & 3.54 & 8.10 & 11.67 & 10.27 & 25.17 & 23.51 & 13.34 \\
& \pm 1.04 & \pm 1.04 & \pm 0.33 & \pm 0.14 & \pm 0.15 & \pm 0.45 & \pm 1.14 & \pm 0.97 \\
\hline \multirow{2}{*}{22} & 1.55 & 1.34 & 3.65 & 10.22 & 15.83 & 36.65 & 20.67 & 10.09 \\
& \pm 0.34 & \pm 0.61 & \pm 0.96 & \pm 1.53 & \pm 1.01 & \pm 0.81 & \pm 2.01 & \pm 1.19 \\
\hline \multirow{2}{*}{23} & 10.11 & 4.48 & 14.60 & 24.13 & 18.08 & 21.01 & 5.73 & 1.86 \\
& \pm 1.80 & \pm 0.39 & \pm 1.14 & \pm 0.67 & \pm 0.47 & \pm 1.34 & \pm 0.90 & \pm 0.29 \\
\hline \multicolumn{8}{|c|}{ Oaxaca } \\
\hline \multirow{2}{*}{24} & 0.47 & 1.15 & 3.97 & 12.15 & 19.12 & 43.74 & 17.57 & 1.83 \\
& \pm 0.28 & \pm 0.25 & \pm 0.38 & \pm 0.38 & \pm 0.34 & \pm 0.43 & \pm 0.37 & \pm 0.35 \\
\hline \multirow{2}{*}{25} & 15.31 & 20.49 & 26.63 & 19.45 & 8.25 & 5.96 & 2.17 & 1.74 \\
& \pm 1.06 & \pm 0.60 & \pm 0.82 & \pm 0.67 & \pm 0.57 & \pm 0.19 & \pm 0.60 & \pm 0.17 \\
\hline \multirow{2}{*}{26} & 1.22 & 1.62 & 3.08 & 11.63 & 18.99 & 41.57 & 18.92 & 2.97 \\
& \pm 0.27 & \pm 0.33 & \pm 0.47 & \pm 0.35 & \pm 0.45 & \pm 0.22 & \pm 0.38 & \pm 0.41 \\
\hline \multicolumn{7}{|c|}{ Nuevo León } \\
\hline \multirow{2}{*}{31} & 1.26 & 3.62 & 9.33 & 20.58 & 20.54 & 26.83 & 13.58 & 4.26 \\
& \pm 0.11 & \pm 0.30 & \pm 0.65 & \pm 0.58 & \pm 0.42 & \pm 0.97 & \pm 0.28 & \pm 0.96 \\
\hline \multicolumn{7}{|c|}{ Sonora } \\
\hline \multirow{2}{*}{32} & 0.87 & 1.54 & 1.08 & 2.07 & 8.36 & 43.58 & 38.24 & 4.26 \\
& \pm 0.09 & \pm 0.29 & \pm 0.43 & \pm 0.35 & \pm 0.28 & \pm 0.63 & \pm 0.41 & \pm 0.28 \\
\hline
\end{tabular}

\section{Proximate Analysis}

Table 3 summarizes the results of the proximate analysis. The moisture content of the dry biomass samples ranged from 5.0\% (Olneya tesota) to 13.2\% (Caesalpinia platyloba). In relation to the results of the ash content of the biomass studied, the values obtained range from $0.27 \%$ (Pinus spp.) to $6.27 \%$ (lemon peel). It is observed that the amount of inorganic substances from the Pinus spp. biomass $(0.27 \%$ to $0.95 \%)$ is less compared to the amount found in tropical woods (1.32\% to $3.38 \%)$ and in oak woods $(1.02 \%$ to $3.12 \%)$, which agrees with the literature (Fengel and Wegener 1983). For citrus residues, the values found ranged from $0.38 \%$ (orange branches) to $6.27 \%$ (lemon peel). Some values are close to the ash content found in apricot stone shell (1.29\%) shell (Fidan and Ertaş 2020).

Tropical woods usually contain a high concentration of mineral substances (Fengel and Wegener 1983), which coincided with the results obtained in this study. However, the values of the amount of ash found here were lower than the reported range $(4.77 \%$ to $7.22 \%$ ) in other tropical woods (Rodríguez-Jiménez et al. 2019). The ash content in the biomass of Pinus spp. was within the typical range (0.1\% to 1.0\%) (UNE-EN 14961-1 2011) and coincided with previous reports for various pine species (Bernabé-Santiago et al. 2013; Correa-Méndez et al. 2014; Pintor-Ibarra et al. 2017). The value for the biomass of oak woods (sample 22), in general coincided with data reported for oak woods (HerreraFernández et al. 2017; Cárdenas-Gutiérrez et al. 2018) and sample 19 presented a high value, perhaps due to a contamination of the sample at the collection site. The amount of ash in citrus branches was within the range reported for branches of various wood species (Ngangyo-Heya et al. 2016; Cárdenas-Gutiérrez et al. 2018). The content of mineral substances is an important characteristic of a solid biofuel (Obernberger and Thek 2010); it allows determining the amount of waste generated in the combustion process and is useful for the design of biomass combustion equipment (Velázquez 2018). The biomass samples studied, whose values are less than $0.70 \%, 1.5 \%$, and $3.0 \%$, could be used to make class A1, class A2, and class B pellets, respectively, as per ISO 17225-2 (2014). Biomass samples with values less than $0.50 \%$ ash could be used to make briquettes as per ÖNORM 7135 (2000), complying with international standards. 
In relation to volatile matter, which is the fraction that is transformed into gas in the combustion process (Velázquez 2018), the values found in biomass ranged from $78.9 \%$ (Pinus spp.) to $90.5 \%$ (orange branches), and in general they were within the range reported for biomass (47.8\% to $86.3 \%$ ) (Vassilev et al. 2010). The ranges found for the wood biomass groups were as follows: tropical woods $(81.7 \%$ to $87.3 \%)$, pine woods $(78.9 \%$ to $89.8 \%$ ), and oak woods ( $82.6 \%$ to $84.9 \%$ ); these are values that in summary coincide with previous reports for various timber species (Telmo et al. 2010; Vassilev et al. 2010; García et al. 2012).

Table 3. Proximate Analysis Data for Biomass Wastes

\begin{tabular}{|c|c|c|c|c|c|c|}
\hline Sample & Origin & Name & Moisture (\%) & Ash (\%) & VM (\%) & CF (\%) \\
\hline 1 & \multirow{6}{*}{$\begin{array}{l}\text { Quintana } \\
\text { Roo }\end{array}$} & $\begin{array}{l}\text { Swartzia } \\
\text { cubensis }\end{array}$ & $8.66 \pm 0.07$ & $1.32 \pm 0.01$ & $85.53 \pm 0.70$ & $13.14 \pm 0.70$ \\
\hline 2 & & $\begin{array}{l}\text { Lysiloma } \\
\text { latisiliquum }\end{array}$ & $9.50 \pm 0.10$ & $3.34 \pm 0.02$ & $87.33 \pm 0.28$ & $9.32 \pm 0.28$ \\
\hline 3 & & $\begin{array}{l}\text { Caesalpinia } \\
\text { platyloba }\end{array}$ & $13.24 \pm 0.13$ & $2.20 \pm 0.03$ & $81.71 \pm 0.14$ & $16.08 \pm 0.14$ \\
\hline 4 & & Manilkara zapota & $10.56 \pm 0.14$ & $3.38 \pm 0.03$ & $82.11 \pm 0.33$ & $14.50 \pm 0.33$ \\
\hline 5 & & $\begin{array}{l}\text { Swartzia } \\
\text { cubensis }\end{array}$ & $9.95 \pm 0.61$ & $2.52 \pm 0.02$ & $83.55 \pm 0.58$ & $13.92 \pm 0.58$ \\
\hline 6 & & $\begin{array}{c}\text { Swietenia } \\
\text { macrophylla }\end{array}$ & $8.51 \pm 0.13$ & $2.14 \pm 0.02$ & $86.43 \pm 0.06$ & $11.42 \pm 0.06$ \\
\hline 7 & \multirow{4}{*}{ Chihuahua } & Pinus spp. & $11.18 \pm 0.13$ & $0.47 \pm 0.01$ & $87.79 \pm 0.54$ & $11.73 \pm 0.54$ \\
\hline 8 & & Pinus spp. & $8.87 \pm 0.26$ & $0.45 \pm 0.01$ & $88.41 \pm 0.36$ & $11.13 \pm 0.36$ \\
\hline 9 & & Pinus spp. & $9.88 \pm 0.09$ & $0.73 \pm 0.03$ & $86.41 \pm 0.37$ & $13.05 \pm 0.37$ \\
\hline 10 & & Pinus spp. & $8.38 \pm 0.11$ & $0.53 \pm 0.01$ & $88.41 \pm 0.29$ & $11.05 \pm 0.29$ \\
\hline 11 & \multirow{5}{*}{ Michoacán } & Pinus spp. & $9.71 \pm 0.06$ & $0.91 \pm 0.06$ & $85.46 \pm 0.78$ & $13.62 \pm 0.78$ \\
\hline 12 & & Pinus spp. & $10.82 \pm 0.07$ & $0.51 \pm 0.05$ & $85.40 \pm 0.16$ & $14.09 \pm 0.16$ \\
\hline 13 & & Pinus spp. & $11.32 \pm 0.08$ & $0.44 \pm 0.06$ & $83.08 \pm 0.26$ & $16.48 \pm 0.26$ \\
\hline 14 & & Pinus spp. & $11.49 \pm 0.06$ & $0.64 \pm 0.02$ & $78.90 \pm 0.12$ & $20.44 \pm 0.12$ \\
\hline 15 & & Pinus spp. & $12.07 \pm 0.11$ & $0.33 \pm 0.01$ & $83.83 \pm 0.17$ & $15.83 \pm 0.17$ \\
\hline 16 & \multirow{8}{*}{ Durango } & Pinus spp. & $10.44 \pm 0.13$ & $0.59 \pm 0.06$ & $88.83 \pm 0.24$ & $10.58 \pm 0.24$ \\
\hline 17 & & Pinus spp. & $9.22 \pm 0.09$ & $0.73 \pm 0.02$ & $86.53 \pm 0.58$ & $12.73 \pm 0.58$ \\
\hline 18 & & Pinus spp. & $7.51 \pm 0.17$ & $0.55 \pm 0.07$ & $86.88 \pm 0.08$ & $12.56 \pm 0.08$ \\
\hline 19 & & Quercus spp. & $12.28 \pm 0.19$ & $3.12 \pm 0.01$ & $82.55 \pm 0.15$ & $14.32 \pm 0.15$ \\
\hline 20 & & Pinus spp. & $12.36 \pm 0.62$ & $0.27 \pm 0.05$ & $84.54 \pm 0.22$ & $15.18 \pm 0.22$ \\
\hline 21 & & Pinus spp. & $11.17 \pm 0.14$ & $0.75 \pm 0.01$ & $85.46 \pm 0.54$ & $13.78 \pm 0.54$ \\
\hline 22 & & Quercus spp. & $12.38 \pm 0.13$ & $1.02 \pm 0.02$ & $84.91 \pm 0.59$ & $14.07 \pm 0.59$ \\
\hline 23 & & Pinus spp. & $12.27 \pm 0.22$ & $0.95 \pm 0.01$ & $82.40 \pm 0.61$ & $16.64 \pm 0.61$ \\
\hline 24 & \multirow{3}{*}{ Oaxaca } & Pinus spp. & $11.83 \pm 0.18$ & $0.66 \pm 0.10$ & $83.34 \pm 0.33$ & $15.99 \pm 0.33$ \\
\hline 25 & & Pinus spp. & $8.44 \pm 0.20$ & $0.35 \pm 0.03$ & $88.83 \pm 0.44$ & $10.82 \pm 0.63$ \\
\hline 26 & & Pinus spp. & $11.47 \pm 0.29$ & $0.48 \pm 0.04$ & $80.38 \pm 0.16$ & $19.13 \pm 0.16$ \\
\hline 27 & \multirow{4}{*}{ Veracruz } & $\begin{array}{l}\text { Persian lime } \\
\text { branches }\end{array}$ & $6.71 \pm 0.29$ & $0.48 \pm 0.18$ & $87.42 \pm 0.97$ & $12.09 \pm 0.97$ \\
\hline 28 & & $\begin{array}{l}\text { Persian lime } \\
\text { leaves }\end{array}$ & $9.69 \pm 0.33$ & \pm 0.34 & $82.17 \pm 0.35$ & $11.71 \pm 0.35$ \\
\hline 29 & & Orange branches & $4.91 \pm 0.17$ & $0.38 \pm 0.03$ & $90.50 \pm 0.24$ & $9.10 \pm 0.24$ \\
\hline 30 & & Lemon peels & $12.29 \pm 0.25$ & $6.27 \pm 0.62$ & $80.39 \pm 0.31$ & $13.33 \pm 0.31$ \\
\hline 31 & Nuevo León & Pinus spp. & $8.78 \pm 0.10$ & $0.51 \pm 0.11$ & $89.84 \pm 0.15$ & $9.64 \pm 0.15$ \\
\hline 32 & Sonora & Olneya tesota & $5.01 \pm 0.22$ & $1.44 \pm 0.22$ & $81.86 \pm 0.62$ & $16.69 \pm 0.15$ \\
\hline
\end{tabular}


Fixed carbon, which is the fraction that is oxidized in the solid phase during the combustion of biomass (Velázquez 2018), ranged from 9.1\% (orange branches) to $20.4 \%$ (Pinus spp.) and was in the reported range (0.5\% to 37.9\%) for biomass (Vassilev et al. 2010). In relation to the wood biomass, the variations are the following: tropical woods ( $9.3 \%$ to $16.7 \%)$, pine woods $(9.6 \%$ to $20.4 \%)$, and oak woods (14.1\% to $14.3 \%)$; these fixed carbon values generally coincided with data reported for various woods (Telmo et al. 2010; Vassilev et al. 2010; García et al. 2012).

\section{Ultimate Analysis}

The results of the ultimate analysis are presented in Table 4 and in general are in agreement with values reported for different types of biomass (Vassilev et al. 2010). The percentage of nitrogen and sulfur in the wood is usually low, but in other parts of the tree the concentration may be higher (Camps and Marcos 2008), as shown by the results on the amount of nitrogen in the citrus biomass. Sulfur was not detected in the samples. Carbon and oxygen are the main components in solid biofuels and are the ones that participate in the exothermic reaction during combustion, generating $\mathrm{CO}_{2}$ and $\mathrm{H}_{2} \mathrm{O}$ (Obernberger et al. 2006). For all biomass samples, the carbon content ranged from $49.1 \%$ (Lysiloma latisiliquum) to $50.8 \%$ (Pinus spp.), oxygen from $42.6 \%$ (lime leaves) to $44.5 \%$ (Lysiloma latisiliquum), and hydrogen from $5.2 \%$ (lemon peel) to 6.6\% (Pinus spp.). These values are lower than the results obtained for apricot stone shell (Fidan and Ertaş 2020).

For wood biomass, the amount of carbon varied as follows: tropical woods (49.1\% to $49.6 \%$ ), pine woods ( $49.6 \%$ to $50.8 \%$ ), and oak woods $(50.0 \%$ to $50.6 \%)$. The oxygen concentration had the following variation: tropical woods (43.6\% to $44.5 \%)$, pine woods ( $42.9 \%$ to $43.9 \%$ ), and oak woods (43.3\% to $43.9 \%)$. The hydrogen content varied as follows: tropical woods (6.0\% to $6.2 \%)$, pine woods (6.2\% to 6.6\%), and oak woods $(6.0 \%$ to $6.0 \%)$. The values obtained here are within the range reported for softwoods (C: 47 to 54\%, O: 40 to $44 \%$, and H: 5.6 to 7.0) and for hardwoods (C: 48 to $52 \%$, O: 41 to $45 \%$, and $\mathrm{H}$ : 5.9 to $6.5 \%$ ) as per ISO 17225-2 (2014). The average values of $\mathrm{C}, \mathrm{O}$, and $\mathrm{H}$ for the sawdust were 50.16, 43.46, and 6.23\%, respectively. For citrus residues, the average amount of carbon was $50.1 \%$, oxygen $43.3 \%$, and hydrogen $5.7 \%$.

Most of the nitrogen is converted to gaseous nitrogen and nitric oxides (NOx) during the combustion process (Obernberger et al. 2006). The nitrogen content ranged in tropical woods from $0.14 \%$ to $0.42 \%$, in pine woods from $0.10 \%$ to $0.74 \%$, and in oak woods from $0.12 \%$ to $0.14 \%$. With the exception of the value of $0.74 \%$ (Pinus spp.), these values coincided with the typical range for coniferous and hardwood woods $(0.10 \%$ to $0.50 \%$ ) as per ISO 17225-2 (2014). In contrast, the biomass of citrus residues contained more nitrogen compared to the biomass of woods, ranging from $0.36 \%$ (branches) to $2.10 \%$ (leaves) and these results were in the range reported for branches $(0.33 \%$ to $2.87 \%)$ and sheets (1.03\% to 3.04\%) (García et al. 2012).

The lowest values of nitrogen were for the sawdust of pine woods, which coincided with the literature (Velázquez 2018), while the highest values corresponded to biomass of tropical woods and citrus residues. In contrast, the $\mathrm{C} / \mathrm{N}$ ratio presents high variability with values from 24 (lime leaves) to 5025 (Pinus spp.). For the evaluation of the nutritional balance of the biomass substrate, where microorganisms participate in the fermentation process, this $\mathrm{C} / \mathrm{N}$ ratio is important and high values indicate little nitrogen availability (Velázquez 2018). 
Table 4. Ultimate Analysis Data for Biomass Wastes

\begin{tabular}{|c|c|c|c|c|c|c|c|}
\hline Sample & Origin & Name & $\mathrm{C}(\%)$ & $\mathrm{H}(\%)$ & $\mathrm{O}(\%)$ & $\mathrm{N}(\%)$ & $\mathrm{C} / \mathrm{N}$ \\
\hline 1 & \multirow{6}{*}{$\begin{array}{l}\text { Quintana } \\
\text { Roo }\end{array}$} & $\begin{array}{l}\text { Swartzia } \\
\text { cubensis }\end{array}$ & 49.62 & 6.19 & 43.77 & 0.42 & 118 \\
\hline 2 & & $\begin{array}{c}\text { Lysiloma } \\
\text { latisiliquum }\end{array}$ & 49.13 & 6.02 & 44.49 & 0.36 & 136 \\
\hline 3 & & $\begin{array}{c}\text { Caesalpinia } \\
\text { platyloba }\end{array}$ & 49.78 & 6.21 & 43.69 & 0.32 & 156 \\
\hline 4 & & $\begin{array}{c}\text { Manilkara } \\
\text { zapota }\end{array}$ & 49.99 & 6.12 & 43.62 & 0.27 & 185 \\
\hline 5 & & $\begin{array}{l}\text { Swartzia } \\
\text { cubensis }\end{array}$ & 49.50 & 6.18 & 44.05 & 0.27 & 183 \\
\hline 6 & & $\begin{array}{c}\text { Swietenia } \\
\text { macrophylla }\end{array}$ & 49.67 & 6.08 & 44.11 & 0.14 & 355 \\
\hline 7 & \multirow{4}{*}{ Chihuahua } & Pinus spp. & 50.35 & 6.28 & 43.29 & 0.08 & 629 \\
\hline 8 & & Pinus spp. & 50.78 & 6.26 & 42.90 & 0.06 & 846 \\
\hline 9 & & Pinus spp. & 50.18 & 6.26 & 43.51 & 0.05 & 1004 \\
\hline 10 & & Pinus spp. & 50.57 & 6.43 & 42.93 & 0.07 & 722 \\
\hline 11 & \multirow{5}{*}{ Michoacán } & Pinus spp. & 50.25 & 6.15 & 43.59 & 0.01 & 5025 \\
\hline 12 & & Pinus spp. & 50.51 & 6.30 & 43.14 & 0.05 & 1010 \\
\hline 13 & & Pinus spp. & 50.71 & 6.20 & 43.03 & 0.06 & 845 \\
\hline 14 & & Pinus spp. & 50.74 & 6.21 & 42.93 & 0.12 & 423 \\
\hline 15 & & Pinus spp. & 50.56 & 6.19 & 43.19 & 0.06 & 843 \\
\hline 16 & \multirow{8}{*}{ Durango } & Pinus spp. & 50.20 & 6.50 & 43.21 & 0.09 & 556 \\
\hline 17 & & Pinus spp. & 49.84 & 6.34 & 43.08 & 0.74 & 67 \\
\hline 18 & & Pinus spp. & 49.63 & 6.55 & 43.74 & 0.08 & 620 \\
\hline 19 & & $\begin{array}{l}\text { Quercus } \\
\text { spp. }\end{array}$ & 50.63 & 5.96 & 43.27 & 0.14 & 362 \\
\hline 20 & & Pinus spp. & 50.59 & 6.31 & 43.01 & 0.09 & 562 \\
\hline 21 & & Pinus spp. & 50.09 & 6.25 & 43.64 & 0.02 & 2505 \\
\hline 22 & & $\begin{array}{l}\text { Quercus } \\
\text { spp. }\end{array}$ & 50.04 & 5.99 & 43.85 & 0.12 & 417 \\
\hline 23 & & Pinus spp. & 50.66 & 6.2 & 43.04 & 0.10 & 507 \\
\hline 24 & \multirow{3}{*}{ Oaxaca } & Pinus spp. & 49.91 & 6.23 & 43.75 & 0.11 & 454 \\
\hline 25 & & Pinus spp. & 50.26 & 6.15 & 43.52 & 0.07 & 718 \\
\hline 26 & & Pinus spp. & 50.73 & 6.21 & 42.96 & 0.10 & 507 \\
\hline 27 & \multirow{4}{*}{ Veracruz } & $\begin{array}{l}\text { Persian } \\
\text { lime } \\
\text { branches }\end{array}$ & 50.10 & 6.01 & 43.35 & 0.54 & 93 \\
\hline 28 & & $\begin{array}{c}\text { Persian } \\
\text { lime leaves }\end{array}$ & 49.57 & 5.71 & 42.62 & 2.10 & 24 \\
\hline 29 & & $\begin{array}{c}\text { Orange } \\
\text { branches }\end{array}$ & 49.89 & 5.87 & 43.88 & 0.36 & 139 \\
\hline 30 & & $\begin{array}{l}\text { Lemon } \\
\text { peels }\end{array}$ & 50.67 & 5.24 & 43.36 & 0.73 & 69 \\
\hline 31 & Nuevo León & Pinus spp. & 49.59 & 6.50 & 43.85 & 0.06 & 827 \\
\hline 32 & Sonora & $\begin{array}{l}\text { Olneya } \\
\text { tesota }\end{array}$ & 49.85 & 6.20 & 43.66 & 0.29 & 172 \\
\hline
\end{tabular}

Knowledge of the elemental composition of biomass is important because it allows predicting the reactions that will occur in the biomass combustion processes and helps to determine the number of reagents, products generated, and the heat given off in them (Velázquez 2018). In contrast, NOx emissions have an environmental impact on the combustion of solid fuels (Nussbaumer 2002), and this increases proportionally with the 
nitrogen content of the biomass (Lyngfelt et al. 1996). Due to the relatively low nitrogen results in the biomass studied, low environmental impact would be expected when used as densified biofuels.

\section{High Heating Value Calculation}

The results of the calorific value calculated using the prediction models based on the ultimate analysis (Demirbaş 1997), proximate analysis (Cordero et al. 2001), and the ash content (Sheng and Azevedo 2005) are presented in Table 5. It is observed that the results obtained by the mathematical model based on elemental analysis were slightly lower than the other two models used.

Table 5. High Heating Value (HHV) Calculated for Biomass Wastes (MJ/kg)

\begin{tabular}{|c|c|c|c|c|c|}
\hline Sample & Origin & Name & $\begin{array}{l}\text { HHV by } \\
\text { Ultimate } \\
\text { Analysis }\end{array}$ & $\begin{array}{l}\text { HHV by } \\
\text { Proximate } \\
\text { Analysis }\end{array}$ & $\begin{array}{c}\text { HHV by } \\
\text { Ash Content }\end{array}$ \\
\hline 1 & \multirow{6}{*}{$\begin{array}{l}\text { Quintana } \\
\text { Roo }\end{array}$} & Swartzia cubensis & 18.63 & 19.26 & 19.61 \\
\hline 2 & & Lysiloma latisiliquum & 18.12 & 18.22 & 19.14 \\
\hline 3 & & Caesalpinia platyloba & 18.74 & 19.65 & 19.40 \\
\hline 4 & & Manilkara zapota & 18.70 & 19.16 & 19.13 \\
\hline 5 & & Swartzia cubensis & 18.55 & 19.20 & 19.33 \\
\hline 6 & & Swietenia macrophylla & 18.48 & 18.81 & 19.42 \\
\hline 7 & \multirow{4}{*}{ Chihuahua } & Pinus spp. & 19.13 & 19.15 & 19.80 \\
\hline 8 & & Pinus spp. & 19.30 & 19.04 & 19.81 \\
\hline 9 & & Pinus spp. & 19.01 & 19.38 & 19.74 \\
\hline 10 & & Pinus spp. & 19.47 & 19.02 & 19.79 \\
\hline 11 & \multirow{5}{*}{ Michoacán } & Pinus spp. & 18.87 & 19.42 & 19.70 \\
\hline 12 & & Pinus spp. & 19.23 & 19.58 & 19.80 \\
\hline 13 & & Pinus spp. & 19.18 & 20.03 & 19.81 \\
\hline 14 & & Pinus spp. & 19.21 & 20.72 & 19.77 \\
\hline 15 & & Pinus spp. & 19.09 & 19.93 & 19.84 \\
\hline 16 & \multirow{8}{*}{ Durango } & Pinus spp. & 19.40 & 18.92 & 19.78 \\
\hline 17 & & Pinus spp. & 18.98 & 19.29 & 19.74 \\
\hline 18 & & Pinus spp. & 19.20 & 19.29 & 19.79 \\
\hline 19 & & Quercus spp. & 18.76 & 19.17 & 19.19 \\
\hline 20 & & Pinus spp. & 19.29 & 19.82 & 19.85 \\
\hline 21 & & Pinus spp. & 18.95 & 19.48 & 19.74 \\
\hline 22 & & Quercus spp. & 18.52 & 19.49 & 19.68 \\
\hline 23 & & Pinus spp. & 19.15 & 19.97 & 19.69 \\
\hline 24 & \multirow{3}{*}{ Oaxaca } & Pinus spp. & 18.83 & 19.90 & 19.76 \\
\hline 25 & & Pinus spp. & 18.88 & 19.01 & 19.83 \\
\hline 26 & & Pinus spp. & 19.20 & 20.51 & 19.80 \\
\hline 27 & \multirow{4}{*}{ Veracruz } & Persian lime branches & 18.58 & 19.21 & 19.80 \\
\hline 28 & & Persian lime leaves & 17.86 & 18.18 & 18.49 \\
\hline 29 & & Orange branches & 18.26 & 18.68 & 19.83 \\
\hline 30 & & Lemon peels & 17.65 & 18.45 & 18.46 \\
\hline 31 & $\begin{array}{l}\text { Nuevo } \\
\text { León }\end{array}$ & Pinus spp. & 19.10 & 18.76 & 19.80 \\
\hline 32 & Sonora & Olneya tesota & 18.76 & 19.89 & 19.58 \\
\hline \multicolumn{3}{|c|}{ Average } & $\begin{array}{l}18.85 \\
\pm 0.43 \\
\end{array}$ & $\begin{array}{l}19.33 \\
\pm 0.58 \\
\end{array}$ & $\begin{array}{l}19.59 \\
\pm 0.36 \\
\end{array}$ \\
\hline
\end{tabular}


For the model based on the last analysis, the calculated calorific value ranged from $17.7 \mathrm{MJ} / \mathrm{kg}$ (lemon peel) to $19.4 \mathrm{MJ} / \mathrm{kg}$ (Pinus spp.). For the biomass groups the variation was as follows: tropical woods from $18.1 \mathrm{MJ} / \mathrm{kg}$ (Lysiloma latisiliquum) to $18.8 \mathrm{MJ} / \mathrm{kg}$ (Olneya tesota), pine woods (18.8 to $19.5 \mathrm{MJ} / \mathrm{kg}$ ), oak woods (18.5 to $18.8 \mathrm{MJ} / \mathrm{kg}$ ), and citrus residues from $17.7 \mathrm{MJ} / \mathrm{kg}$ (lemon peels) to $18.6 \mathrm{MJ} / \mathrm{kg}$ (lime branches).

For the model based on proximate analysis, the calorific value results ranged from 18.2 (lime leaves) to $20.7 \mathrm{MJ} / \mathrm{kg}$ (Pinus spp.), and the variation in the biomass groups was as follows: tropical ones of $18.2 \mathrm{MJ} / \mathrm{kg}$ (Lysiloma latisiliquum) at $19.9 \mathrm{MJ} / \mathrm{kg}$ (Olneya tesota), pine woods (18.8 to $20.7 \mathrm{MJ} / \mathrm{kg}$ ), oak woods (19.2 to $19.5 \mathrm{MJ} / \mathrm{kg}$ ), and citrus residues of $18.2 \mathrm{MJ} / \mathrm{kg}$ (lime leaves) at $19.2 \mathrm{MJ} / \mathrm{kg}$ (lime branches).

For the results obtained with the model based on the amount of ash, the values ranged from 18.5 (lemon peel) to $19.9 \mathrm{MJ} / \mathrm{kg}$ (Pinus spp.). For the biomass groups, the variation of the calorific value was as follows: tropical from $19.1 \mathrm{MJ} / \mathrm{kg}$ (Lysiloma latisiliquum) to $19.6 \mathrm{MJ} / \mathrm{kg}$ (Swartzia cubensis), pine woods (19.7 to $19.9 \mathrm{MJ} / \mathrm{kg}$ ), oak woods (19.2 to $19.7 \mathrm{MJ} / \mathrm{kg}$ ), and citrus residues from $18.5 \mathrm{MJ} / \mathrm{kg}$ (lemon peels) to 19.8 $\mathrm{MJ} / \mathrm{kg}$ (orange branches).

According to the results obtained by the three mathematical equations used, the values of the calorific value for the group of tropical woods $(18.1$ to $19.6 \mathrm{MJ} / \mathrm{kg})$, in general were greater than the range (16.2 to $18.5 \mathrm{MJ} / \mathrm{kg}$ ) obtained by calculation with a mathematical model based on elemental analysis for woods of other tropical species (Rodríguez-Jiménez et al. 2019), but they were slightly less than the experimental data reported for some tropical woods (19.0 to $20.7 \mathrm{MJ} / \mathrm{kg}$ ) (Telmo et al. 2010 ). Likewise, this study's average values for the biomass group of pine (18.8 to $20.7 \mathrm{MJ} / \mathrm{kg}$ ) and oak (18.5 to $19.7 \mathrm{MJ} / \mathrm{kg}$ ) were within the range of typical variation reported for softwoods (18.5 to 19.8 $\mathrm{MJ} / \mathrm{kg}$ ) and for hardwoods (18.4 to $19.2 \mathrm{MJ} / \mathrm{kg}$ ) as per UNE-EN 14961-1 (2011).

\section{Ash Microanalysis}

The following tables (Table 6 to $6 \mathrm{~d}$ ) show the microanalysis data of the ashes of all the biomasses studied. In this study 23 chemical elements were detected, and there was variability in the concentration and in the number of chemical elements present in each biomass. For the tropical wood group, the concentration varied from $0.89 \mathrm{ppm}(\mathrm{Cr}$ in Lysiloma latisiliquum) to $228,498 \mathrm{ppm}$ ( $\mathrm{K}$ in Caesalpinia platyloba), in the pine wood group from $0.01 \mathrm{ppm}$ (As, Mo) to 29,166 ppm (Ca), in the oak wood group from $0.53 \mathrm{ppm}$ $(\mathrm{V})$ to $378,271 \mathrm{ppm}(\mathrm{K})$, in citrus branches from $1.64 \mathrm{ppm}(\mathrm{Cr}$ in orange branches) to $29,480 \mathrm{ppm}$ ( $\mathrm{P}$ in lime branches), in lime leaves from $0.22 \mathrm{ppm}(\mathrm{Cr})$ to $259,108 \mathrm{ppm}(\mathrm{K})$, and in lemon peels from $1.03 \mathrm{ppm}(\mathrm{Co})$ to $282,617 \mathrm{ppm}(\mathrm{K})$.

Major elements that constitute the ash are considered $\mathrm{Al}, \mathrm{Ca}, \mathrm{Fe}, \mathrm{K}, \mathrm{Mg}, \mathrm{Mn}, \mathrm{Na}$, $\mathrm{P}, \mathrm{Si}$, and Ti (UNE-EN 14961-1 2011) and are important in the characterization of the ashes of a biofuel (Velázquez 2018); the only one not detected here was Ti. The minor elements present in solid biofuels are considered $\mathrm{As}, \mathrm{Cd}, \mathrm{Cr}, \mathrm{Co}, \mathrm{Cu}, \mathrm{Hg}, \mathrm{Ni}, \mathrm{Pb}, \mathrm{V}$, and Zn (UNE-EN 14961-1 2011), of which Hg was not detected in the samples of biomass studied here. Other chemical elements detected here were B, Ba, Li, Mo, and Sr. The typical chemical elements present in wood are $\mathrm{Ca}, \mathrm{K}, \mathrm{Mg}, \mathrm{Mn}, \mathrm{Na}, \mathrm{P}$, and $\mathrm{Cl}$ (Fengel and Wegener 1983), with the exception of $\mathrm{Cl}$, all were detected here. In general, the results of the microanalysis of the ashes coincide with previous studies carried out on different species of wood (Rutiaga-Quiñones and García-Díaz 1999; Villaseñor-Araiza and RutiagaQuiñones 2000; Bernabé-Santiago et al. 2013; Correa-Méndez et al. 2013; Correa-Méndez et al. 2014; Ávila-Calderón and Rutiaga-Quiñones 2015; Martínez-Pérez et al. 2015; 
Ngangyo-Heya et al. 2016; Pintor-Ibarra et al. 2017; Cárdenas-Gutiérrez et al. 2018; RuízAquino et al. 2019).

Table 6. Ash Microanalysis Data for Biomass Wastes (ppm)

\begin{tabular}{|c|c|c|c|c|c|c|c|}
\hline Sample & Origin & Name & $\mathrm{Al}$ & As & $\mathrm{B}$ & $\mathrm{Ba}$ & $\mathrm{Ca}$ \\
\hline 1 & \multirow{6}{*}{ Quintana Roo } & $\begin{array}{l}\text { Swartzia } \\
\text { cubensis }\end{array}$ & 1652 & 10.21 & 161.90 & 50.29 & 26474 \\
\hline 2 & & $\begin{array}{l}\text { Lysiloma } \\
\text { latisiliquum }\end{array}$ & 1017 & 6.32 & 116.25 & 42.48 & 18600 \\
\hline 3 & & $\begin{array}{c}\text { Caesalpinia } \\
\text { platyloba }\end{array}$ & 4352 & 0.00 & 88.98 & 56.36 & 23057 \\
\hline 4 & & $\begin{array}{c}\text { Manilkara } \\
\text { zapota }\end{array}$ & 1277 & 0.00 & 76.00 & 33.49 & 20475 \\
\hline 5 & & $\begin{array}{l}\text { Swartzia } \\
\text { cubensis }\end{array}$ & 2033 & 8.71 & 119.49 & 50.00 & 21216 \\
\hline 6 & & $\begin{array}{c}\text { Swietenia } \\
\text { macrophylla }\end{array}$ & 1536 & 0.00 & 78.80 & 402.97 & 24200 \\
\hline 7 & \multirow{4}{*}{ Chihuahua } & Pinus spp. & 8811 & 4.19 & 173.84 & 549.02 & 27252 \\
\hline 8 & & Pinus spp. & 3301 & 2.96 & 158.97 & 905.76 & 26830 \\
\hline 9 & & Pinus spp. & 9474 & 5.08 & 205.46 & 994.15 & 28069 \\
\hline 10 & & Pinus spp. & 9863 & 8.58 & 193.64 & 571.12 & 23260 \\
\hline 11 & \multirow{5}{*}{ Michoacán } & Pinus spp. & 14926 & 0.00 & 192.14 & 247.87 & 22213 \\
\hline 12 & & Pinus spp. & 11882 & 0.00 & 453.23 & 676.10 & 27518 \\
\hline 13 & & Pinus spp. & 17618 & 0.00 & 225.12 & 273.60 & 22318 \\
\hline 14 & & Pinus spp. & 14153 & 0.00 & 228.46 & 272.23 & 24196 \\
\hline 15 & & Pinus spp. & 17544 & 0.00 & 285.99 & 274.44 & 24830 \\
\hline 16 & \multirow{8}{*}{ Durango } & Pinus spp. & 6691 & 0.01 & 224.93 & 980.67 & 23476 \\
\hline 17 & & Pinus spp. & 2367 & 0.01 & 209.17 & 589.02 & 19257 \\
\hline 18 & & Pinus spp. & 8854 & 0.44 & 224.86 & 969.51 & 25859 \\
\hline 19 & & Quercus spp. & 1886 & 0.00 & 205.92 & 906.79 & 29036 \\
\hline 20 & & Pinus spp. & 9368 & 0.25 & 226.67 & 872.71 & 25852 \\
\hline 21 & & Pinus spp. & 4175 & 0.01 & 190.51 & 962.63 & 29166 \\
\hline 22 & & Quercus spp. & 3035 & 0.00 & 184.41 & 919.61 & 27608 \\
\hline 23 & & Pinus spp. & 4101 & 0.01 & 183.89 & 846.27 & 27573 \\
\hline 24 & \multirow{3}{*}{ Oaxaca } & Pinus spp. & 21793 & 20.18 & 178.05 & 283.00 & 19032 \\
\hline 25 & & Pinus spp. & 18713 & 14.36 & 710.23 & 241.00 & 23850 \\
\hline 26 & & Pinus spp. & 12669 & 23.60 & 182.59 & 191.62 & 18373 \\
\hline 27 & \multirow{4}{*}{ Veracruz } & $\begin{array}{l}\text { Persian lime } \\
\text { branches }\end{array}$ & 239.12 & 0.00 & 225.37 & 940.93 & 24031 \\
\hline 28 & & $\begin{array}{l}\text { Persian lime } \\
\text { leaves }\end{array}$ & 372.40 & 0.00 & 359.69 & 1938 & 22220 \\
\hline 29 & & $\begin{array}{l}\text { Orange } \\
\text { branches }\end{array}$ & 639.86 & 0.00 & 168.83 & 658.83 & 23796 \\
\hline 30 & & Lemon peels & 4407 & 0.00 & 220.25 & 1423 & 20983 \\
\hline 31 & Nuevo León & Pinus spp. & 11536 & 9.02 & 153.27 & 592.54 & 23234 \\
\hline 32 & Sonora & $\begin{array}{l}\text { Olneya } \\
\text { tesota }\end{array}$ & 1257 & 0.00 & 56.25 & 83.63 & 20463 \\
\hline
\end{tabular}


Table 6a. Ash Microanalysis Data for Biomass Wastes (ppm)

\begin{tabular}{|c|c|c|c|c|c|c|c|}
\hline Sample & Origin & Name & $\mathrm{Cd}$ & Co & $\mathrm{Cr}$ & $\mathrm{Cu}$ & $\mathrm{Fe}$ \\
\hline 1 & \multirow{6}{*}{ Quintana Roo } & $\begin{array}{l}\text { Swartzia } \\
\text { cubensis }\end{array}$ & 0.00 & 0.00 & 10.78 & 34.00 & 2580 \\
\hline 2 & & $\begin{array}{l}\text { Lysiloma } \\
\text { latisiliquum }\end{array}$ & 0.00 & 0.00 & 0.89 & 20.21 & 682.44 \\
\hline 3 & & $\begin{array}{c}\text { Caesalpinia } \\
\text { platyloba }\end{array}$ & 0.00 & 0.00 & 2.23 & 28.92 & 2127 \\
\hline 4 & & $\begin{array}{c}\text { Manilkara } \\
\text { zapota }\end{array}$ & 0.00 & 0.00 & 4.32 & 26.26 & 814.00 \\
\hline 5 & & $\begin{array}{l}\text { Swartzia } \\
\text { cubensis }\end{array}$ & 0.00 & 0.00 & 10.90 & 44.36 & 2794 \\
\hline 6 & & $\begin{array}{c}\text { Swietenia } \\
\text { macrophylla }\end{array}$ & 0.00 & 0.00 & 9.51 & 56.64 & 1351 \\
\hline 7 & \multirow{4}{*}{ Chihuahua } & Pinus spp. & 0.00 & 0.00 & 15.51 & 100.51 & 9249 \\
\hline 8 & & Pinus spp. & 0.00 & 0.00 & 12.87 & 103.59 & 2874 \\
\hline 9 & & Pinus spp. & 0.00 & 0.00 & 58.78 & 130.93 & 7253 \\
\hline 10 & & Pinus spp. & 0.00 & 0.00 & 19.15 & 104.75 & 7769 \\
\hline 11 & \multirow{5}{*}{ Michoacán } & Pinus spp. & 0.00 & 0.00 & 39.31 & 118.98 & 9699 \\
\hline 12 & & Pinus spp. & 0.00 & 0.00 & 26.53 & 131.34 & 9356 \\
\hline 13 & & Pinus spp. & 0.00 & 0.00 & 15.06 & 103.09 & 7769 \\
\hline 14 & & Pinus spp. & 0.00 & 0.00 & 23.33 & 108.26 & 9854 \\
\hline 15 & & Pinus spp. & 0.00 & 0.00 & 14.90 & 117.21 & 4705 \\
\hline 16 & \multirow{8}{*}{ Durango } & Pinus spp. & 0.00 & 0.00 & 7.26 & 102.06 & 4780 \\
\hline 17 & & Pinus spp. & 0.00 & 0.00 & 7.54 & 162.17 & 1928 \\
\hline 18 & & Pinus spp. & 0.00 & 0.00 & 6.51 & 112.64 & 4972 \\
\hline 19 & & Quercus spp. & 0.00 & 0.00 & 2.49 & 35.23 & 1598 \\
\hline 20 & & Pinus spp. & 0.00 & 0.00 & 8.83 & 244.01 & 8491 \\
\hline 21 & & Pinus spp. & 0.00 & 0.00 & 1.62 & 137.90 & 2812 \\
\hline 22 & & Quercus spp. & 0.00 & 0.00 & 1.98 & 31.74 & 2311 \\
\hline 23 & & Pinus spp. & 0.00 & 0.00 & 2.09 & 134.76 & 2758 \\
\hline 24 & \multirow{3}{*}{ Oaxaca } & Pinus spp. & 0.00 & 0.00 & 18.87 & 124.33 & 4439 \\
\hline 25 & & Pinus spp. & 0.00 & 0.00 & 62.73 & 188.18 & 7750 \\
\hline 26 & & Pinus spp. & 0.00 & 0.00 & 11.10 & 190.36 & 8970 \\
\hline 27 & \multirow{4}{*}{ Veracruz } & $\begin{array}{l}\text { Persian lime } \\
\text { branches }\end{array}$ & 0.00 & 0.00 & 0.00 & 72.77 & 509.10 \\
\hline 28 & & $\begin{array}{c}\text { Persian lime } \\
\text { leaves }\end{array}$ & 0.00 & 0.00 & 0.22 & 31.89 & 707.13 \\
\hline 29 & & $\begin{array}{c}\text { Orange } \\
\text { branches }\end{array}$ & 0.00 & 0.00 & 1.64 & 23.83 & 720.84 \\
\hline 30 & & Lemon peels & 0.00 & 1.03 & 9.47 & 124.11 & 5297 \\
\hline 31 & Nuevo León & Pinus spp. & 0.00 & 0.00 & 8.72 & 100.76 & 7729 \\
\hline 32 & Sonora & $\begin{array}{l}\text { Olneya } \\
\text { tesota }\end{array}$ & 0.00 & 0.00 & 4.22 & 36.55 & 819.02 \\
\hline
\end{tabular}


Table 6b. Ash Microanalysis Data for Biomass Wastes (ppm)

\begin{tabular}{|c|c|c|c|c|c|c|c|}
\hline Sample & Origin & Name & $\mathrm{K}$ & $\mathrm{Li}$ & $\mathrm{Mg}$ & $\mathrm{Mn}$ & Mo \\
\hline 1 & \multirow{6}{*}{ Quintana Roo } & $\begin{array}{l}\text { Swartzia } \\
\text { cubensis }\end{array}$ & 222886 & 13.35 & 2404 & 70.66 & 1.67 \\
\hline 2 & & $\begin{array}{l}\text { Lysiloma } \\
\text { latisiliquum }\end{array}$ & 187808 & 11.73 & 2452 & 18.91 & 2.44 \\
\hline 3 & & $\begin{array}{l}\text { Caesalpinia } \\
\text { platyloba }\end{array}$ & 228498 & 63.21 & 2739 & 65.18 & 1.79 \\
\hline 4 & & $\begin{array}{c}\text { Manilkara } \\
\text { zapota }\end{array}$ & 201690 & 14.17 & 3286 & 34.78 & 1.93 \\
\hline 5 & & $\begin{array}{l}\text { Swartzia } \\
\text { cubensis }\end{array}$ & 216887 & 39.45 & 1830 & 70.66 & 1.43 \\
\hline 6 & & $\begin{array}{c}\text { Swietenia } \\
\text { macrophylla }\end{array}$ & 158314 & 12.32 & 2042 & 50.13 & 0.00 \\
\hline 7 & \multirow{4}{*}{ Chihuahua } & Pinus spp. & 345656 & 16.48 & 8332 & 3076 & 0.01 \\
\hline 8 & & Pinus spp. & 353328 & 14.67 & 7067 & 5652 & 0.01 \\
\hline 9 & & Pinus spp. & 357993 & 13.13 & 7494 & 6746 & 0.86 \\
\hline 10 & & Pinus spp. & 201688 & 11.32 & 6440 & 3434 & 0.01 \\
\hline 11 & \multirow{5}{*}{ Michoacán } & Pinus spp. & 43566 & 7.09 & 7730 & 3854 & 2.32 \\
\hline 12 & & Pinus spp. & 40331 & 6.65 & 8191 & 6422 & 0.36 \\
\hline 13 & & Pinus spp. & 43839 & 7.19 & 7451 & 4069 & 0.82 \\
\hline 14 & & Pinus spp. & 46601 & 8.25 & 7287 & 3486 & 0.84 \\
\hline 15 & & Pinus spp. & 37535 & 9.72 & 7595 & 2672 & 1.61 \\
\hline 16 & \multirow{8}{*}{ Durango } & Pinus spp. & 362167 & 5.53 & 7761 & 6129 & 0.00 \\
\hline 17 & & Pinus spp. & 263570 & 2.81 & 6243 & 4120 & 0.00 \\
\hline 18 & & Pinus spp. & 366982 & 7.04 & 7708 & 5963 & 0.00 \\
\hline 19 & & Quercus spp. & 378271 & 7.01 & 6597 & 4671 & 0.00 \\
\hline 20 & & Pinus spp. & 385963 & 6.88 & 7203 & 5898 & 0.00 \\
\hline 21 & & Pinus spp. & 241219 & 9.67 & 5886 & 3919 & 0.00 \\
\hline 22 & & Quercus spp. & 315395 & 9.65 & 5475 & 3679 & 0.00 \\
\hline 23 & & Pinus spp. & 219526 & 8.26 & 5190 & 3488 & 0.00 \\
\hline 24 & \multirow{3}{*}{ Oaxaca } & Pinus spp. & 299074 & 10.28 & 5927 & 5169 & 2.16 \\
\hline 25 & & Pinus spp. & 326979 & 19.69 & 6782 & 6549 & 1.09 \\
\hline 26 & & Pinus spp. & 232913 & 14.35 & 5974 & 3092 & 2.49 \\
\hline 27 & \multirow{4}{*}{ Veracruz } & $\begin{array}{c}\text { Persian lime } \\
\text { branches }\end{array}$ & 281157 & 17.66 & 5629 & 322.09 & 0.00 \\
\hline 28 & & $\begin{array}{l}\text { Persian lime } \\
\text { leaves }\end{array}$ & 259108 & 17.12 & 5144 & 915.58 & 0.00 \\
\hline 29 & & $\begin{array}{c}\text { Orange } \\
\text { branches }\end{array}$ & 235380 & 11.43 & 3631 & 67.26 & 0.00 \\
\hline 30 & & Lemon peels & 282617 & 9.27 & 5662 & 4276 & 1.10 \\
\hline 31 & Nuevo León & Pinus spp. & 201598 & 10.63 & 6428 & 3479 & 0.00 \\
\hline 32 & Sonora & $\begin{array}{l}\text { Olneya } \\
\text { tesota }\end{array}$ & 201578 & 16.17 & 3265 & 36.62 & 2.04 \\
\hline
\end{tabular}


Table 6c. Ash Microanalysis Data for Biomass Wastes (ppm)

\begin{tabular}{|c|c|c|c|c|c|c|c|}
\hline Sample & Origin & Name & $\mathrm{Na}$ & $\mathrm{Ni}$ & $P$ & $\mathrm{~Pb}$ & $\mathrm{Si}$ \\
\hline 1 & \multirow{6}{*}{ Quintana Roo } & $\begin{array}{l}\text { Swartzia } \\
\text { cubensis }\end{array}$ & 1019 & 77.31 & 1294 & 0.00 & 2175 \\
\hline 2 & & $\begin{array}{l}\text { Lysiloma } \\
\text { latisiliquum }\end{array}$ & 1091 & 17.19 & 427.17 & 0.00 & 848.28 \\
\hline 3 & & $\begin{array}{c}\text { Caesalpinia } \\
\text { platyloba }\end{array}$ & 1100 & 35.10 & 730.24 & 0.00 & 799.58 \\
\hline 4 & & $\begin{array}{c}\text { Manilkara } \\
\text { zapota }\end{array}$ & 876.10 & 1267.03 & 374.54 & 180.54 & 562.85 \\
\hline 5 & & $\begin{array}{l}\text { Swartzia } \\
\text { cubensis }\end{array}$ & 906.73 & 123.49 & 1912 & 29.60 & 1584 \\
\hline 6 & & $\begin{array}{c}\text { Swietenia } \\
\text { macrophylla }\end{array}$ & 892.25 & 271.73 & 975.58 & 68.92 & 397.25 \\
\hline 7 & \multirow{4}{*}{ Chihuahua } & Pinus spp. & 1152 & 511.87 & 5504 & 148.82 & 1588 \\
\hline 8 & & Pinus spp. & 1682 & 949.19 & 5425 & 110.27 & 1643 \\
\hline 9 & & Pinus spp. & 1906 & 571.90 & 6025 & 161.53 & 1638 \\
\hline 10 & & Pinus spp. & 1619 & 249.30 & 5610 & 340.59 & 2568 \\
\hline 11 & \multirow{5}{*}{ Michoacán } & Pinus spp. & 548.02 & 650.75 & 6512 & 289.19 & 1341 \\
\hline 12 & & Pinus spp. & 975.77 & 798.80 & 5574 & 948.77 & 3827 \\
\hline 13 & & Pinus spp. & 474.94 & 183.40 & 6342 & 226.81 & 3565 \\
\hline 14 & & Pinus spp. & 575.75 & 326.27 & 7611 & 828.82 & 2204 \\
\hline 15 & & Pinus spp. & 637.86 & 391.12 & 9229 & 880.76 & 3119 \\
\hline 16 & \multirow{8}{*}{ Durango } & Pinus spp. & 1661 & 781.26 & 8744 & 87.40 & 3687 \\
\hline 17 & & Pinus spp. & 1440 & 392.11 & 5228 & 31.00 & 1553 \\
\hline 18 & & Pinus spp. & 1377 & 412.94 & 7112 & 98.99 & 4182 \\
\hline 19 & & Quercus spp. & 1199 & 133.96 & 7538 & 72.01 & 1479 \\
\hline 20 & & Pinus spp. & 1213 & 155.61 & 6823 & 26.27 & 1181 \\
\hline 21 & & Pinus spp. & 1109 & 115.22 & 5426 & 40.83 & 2774 \\
\hline 22 & & Quercus spp. & 1024 & 357.36 & 5192 & 18.20 & 2165 \\
\hline 23 & & Pinus spp. & 1969 & 482.37 & 4850 & 19.52 & 1583 \\
\hline 24 & \multirow{3}{*}{ Oaxaca } & Pinus spp. & 400.13 & 859.92 & 6225 & 23.58 & 726.68 \\
\hline 25 & & Pinus spp. & 615.46 & 927.15 & 8793 & 89.08 & 106.45 \\
\hline 26 & & Pinus spp. & 325.19 & 154.97 & 8832 & 92.52 & 110.81 \\
\hline 27 & \multirow{4}{*}{ Veracruz } & $\begin{array}{c}\text { Persian lime } \\
\text { branches }\end{array}$ & 1081 & 50.43 & 29480 & 27.03 & 0.00 \\
\hline 28 & & $\begin{array}{c}\text { Persian lime } \\
\text { leaves }\end{array}$ & 1883 & 12.77 & 14055 & 0.00 & 1055 \\
\hline 29 & & $\begin{array}{l}\text { Orange } \\
\text { branches }\end{array}$ & 797.07 & 11.41 & 5811 & 9.71 & 37.55 \\
\hline 30 & & Lemon peels & 1731 & 328.67 & 11433 & 197.19 & 248.29 \\
\hline 31 & Nuevo León & Pinus spp. & 1639 & 253.35 & 5608 & 361.27 & 2598 \\
\hline 32 & Sonora & $\begin{array}{l}\text { Olneya } \\
\text { tesota }\end{array}$ & 689.16 & 1299 & 405.45 & 196.12 & 624.11 \\
\hline
\end{tabular}


Table 6d. Ash Microanalysis Data for Biomass Wastes (ppm)

\begin{tabular}{|c|c|c|c|c|c|}
\hline Sample & Origin & Name & $\mathrm{Sr}$ & $\mathrm{V}$ & $\mathrm{Zn}$ \\
\hline 1 & \multirow{6}{*}{ Quintana Roo } & Swartzia cubensis & 280.77 & 0.00 & 45.15 \\
\hline 2 & & Lysiloma latisiliquum & 309.08 & 0.00 & 20.05 \\
\hline 3 & & Caesalpinia platyloba & 312.82 & 0.92 & 56.13 \\
\hline 4 & & Manilkara zapota & 361.05 & 0.00 & 99.11 \\
\hline 5 & & Swartzia cubensis & 323.75 & 0.00 & 70.11 \\
\hline 6 & & Swietenia macrophylla & 158.56 & 0.00 & 126.10 \\
\hline 7 & \multirow{4}{*}{ Chihuahua } & Pinus spp. & 437.02 & 18.01 & 649.38 \\
\hline 8 & & Pinus spp. & 427.55 & 10.08 & 926.46 \\
\hline 9 & & Pinus spp. & 469.51 & 19.97 & 969.33 \\
\hline 10 & & Pinus spp. & 490.93 & 13.29 & 584.49 \\
\hline 11 & \multirow{5}{*}{ Michoacán } & Pinus spp. & 218.74 & 36.80 & 643.09 \\
\hline 12 & & Pinus spp. & 617.29 & 19.80 & 995.25 \\
\hline 13 & & Pinus spp. & 333.33 & 13.23 & 910.75 \\
\hline 14 & & Pinus spp. & 293.14 & 16.85 & 737.93 \\
\hline 15 & & Pinus spp. & 372.57 & 16.80 & 987.39 \\
\hline 16 & \multirow{8}{*}{ Durango } & Pinus spp. & 437.37 & 3.86 & 865.56 \\
\hline 17 & & Pinus spp. & 249.01 & 0.40 & 709.81 \\
\hline 18 & & Pinus spp. & 396.69 & 4.08 & 908.40 \\
\hline 19 & & Quercus spp. & 449.76 & 0.53 & 123.73 \\
\hline 20 & & Pinus spp. & 305.40 & 7.25 & 953.80 \\
\hline 21 & & Pinus spp. & 528.88 & 1.48 & 294.77 \\
\hline 22 & & Quercus spp. & 484.07 & 0.62 & 222.43 \\
\hline 23 & & Pinus spp. & 422.20 & 2.46 & 250.57 \\
\hline 24 & \multirow{3}{*}{ Oaxaca } & Pinus spp. & 196.48 & 25.91 & 419.73 \\
\hline 25 & & Pinus spp. & 257.95 & 15.47 & 529.29 \\
\hline 26 & & Pinus spp. & 168.20 & 32.43 & 407.40 \\
\hline 27 & \multirow{4}{*}{ Veracruz } & Persian lime branches & 1235 & 0.00 & 166.30 \\
\hline 28 & & Persian lime leaves & 1158 & 0.00 & 86.88 \\
\hline 29 & & Orange branches & 691.66 & 9.98 & 50.92 \\
\hline 30 & & Lemon peels & 676.78 & 9.87 & 625.08 \\
\hline 31 & Nuevo León & Pinus spp. & 495.93 & 9.33 & 574.89 \\
\hline 32 & Sonora & Olneya tesota & 386.87 & 0.00 & 100.07 \\
\hline
\end{tabular}

With the results of the microanalysis of the biomass samples, concentration limits were established and the chemical elements were grouped from highest to lowest concentration for the biomass of tropical woods (Table 7), for the biomass from pine sawdust (Table 8), and for the biomass of oak sawdust and citrus residues (Table 9). It is clearly apparent that the most abundant chemical elements present in lignocellulosic materials are $\mathrm{K}$ and $\mathrm{Ca}$, and in some cases $\mathrm{Al}$ and $\mathrm{P}$ (Tables 7, 8, and 9). In general, for tropical woods the highest number of chemical elements was in the range of 99 to $10 \mathrm{ppm}$ (Table 7), the group of pine woods was in the range of 990 to $100 \mathrm{ppm}$ (Table 8), the oak woods was in the range of 9,900 to 1,000 ppm (Table 9), and the citrus residues were in the range of 990 to $100 \mathrm{ppm}$ (Table 9).

In relation to the major elements detected in tropical woods, most of them were in the concentration range of 990 to $100 \mathrm{ppm}$ and higher (Table 7), as well as citrus residues (Table 9) and for the pine woods was in the 9,900 to 1,000 ppm range (Table 8) as well as 
oak woods (Table 9). The major elements are of particular importance in the ash melting point, in the formation of slag, and in corrosion problems, while the minor elements are important in terms of the emission of fine particles and problems of environmental contamination (Telmo et al. 2010). The relative high concentration of the main major chemical elements, mainly $\mathrm{K}$, could be a limitation for the use of these biomasses in the production of densified biofuels, because this element can decrease the melting point of ash and cause problems of formation of slag and deposit formation, in addition to aerosol formation and fine particle emission (Obernberger and Thek 2004; Van Lith et al. 2006).

The distribution of the minor elements present in the biomass samples studied was as follows. In tropical woods they were located from 99 to $10 \mathrm{ppm}$ and lower (Table 7), in pine, oak, and citrus residues from 990 to $100 \mathrm{ppm}$ and lower (Tables 9), even some of them were not detected. The typical values of the major chemical elements in European woods in mg/kg are as follows: conifers Ca (900), K (400), Mg (150), Si (150), Al (100), Mn (100), P (60), Fe (25), Na (20), and Ti (<20); in broadleaf Ca (1200), K (800), Mg (200), Si (150), P (100), Mn (83), Na (50), Fe (25), Al (20), and Ti (<20).

Table 7. Upper-limit Values of Elements in Tropical Wood Samples

\begin{tabular}{|c|c|c|c|c|c|c|c|}
\hline $\begin{array}{l}\text { Range of } \\
\text { Upper- } \\
\text { limit } \\
\text { Values } \\
\text { (ppm) }\end{array}$ & $\begin{array}{l}\text { Swartzia } \\
\text { cubensis }\end{array}$ & $\begin{array}{l}\text { Lysiloma } \\
\text { latisiliquum }\end{array}$ & $\begin{array}{c}\text { Caesalpina } \\
\text { platyloba }\end{array}$ & $\begin{array}{c}\text { Manilkara } \\
\text { zapota }\end{array}$ & $\begin{array}{l}\text { Swartzia } \\
\text { cubensis }\end{array}$ & $\begin{array}{c}\text { Swietenia } \\
\text { macrophylla }\end{array}$ & $\begin{array}{l}\text { Olneya } \\
\text { resota }\end{array}$ \\
\hline $\begin{array}{c}400,000 \\
\text { to } \\
200,000\end{array}$ & $\mathrm{Ca}>\mathrm{K}$ & & K & K & K & & K \\
\hline $\begin{array}{c}199,000 \\
\text { to } \\
100,000\end{array}$ & & K & & & & K & \\
\hline $\begin{array}{c}99,000 \text { to } \\
10,000\end{array}$ & & $\mathrm{Ca}$ & $\mathrm{Ca}$ & $\mathrm{Ca}$ & $\mathrm{Ca}$ & $\mathrm{Ca}$ & $\mathrm{Ca}$ \\
\hline $\begin{array}{c}9,900 \text { to } \\
1,000\end{array}$ & $\begin{array}{c}\mathrm{Fe}>\mathrm{Mg} \\
>\mathrm{Si}> \\
\mathrm{Al}>\mathrm{P}> \\
\mathrm{Na}\end{array}$ & $\begin{array}{c}\mathrm{Mg}>\mathrm{Al}> \\
\mathrm{Na}\end{array}$ & $\begin{array}{c}\mathrm{Al}>\mathrm{Mg}> \\
\mathrm{Fe}>\mathrm{Na}\end{array}$ & $\begin{array}{c}\mathrm{Mg}>\mathrm{Al}> \\
\mathrm{Ni}\end{array}$ & $\begin{array}{c}\mathrm{Al}>\mathrm{Fe} \\
>\mathrm{P}> \\
\mathrm{Mg}>\mathrm{Si}\end{array}$ & $\begin{array}{c}\mathrm{Mg}>\mathrm{Al}> \\
\mathrm{Fe}\end{array}$ & $\begin{array}{l}\mathrm{Mg}> \\
\mathrm{Ni}>\mathrm{Al}\end{array}$ \\
\hline $\begin{array}{l}990 \text { to } \\
100\end{array}$ & $\mathrm{Sr}>\mathrm{B}$ & $\begin{array}{c}\mathrm{Si}>\mathrm{Fe}> \\
\mathrm{P}> \\
\mathrm{Sr}>\mathrm{B}\end{array}$ & $\mathrm{Si}>\mathrm{P}>\mathrm{Sr}$ & $\begin{array}{c}\mathrm{Na}>\mathrm{Fe} \\
>\mathrm{Si}> \\
\mathrm{P}>\mathrm{Sr}> \\
\mathrm{Pb}\end{array}$ & $\begin{array}{c}\mathrm{Na}>\mathrm{Sr} \\
> \\
>\mathrm{B}>\mathrm{Ni}\end{array}$ & $\begin{array}{c}\mathrm{P}>\mathrm{Na}> \\
\mathrm{Ba}>\mathrm{Si}> \\
\mathrm{Ni}>\mathrm{Sr}>\mathrm{Zn}\end{array}$ & $\begin{array}{c}\mathrm{Fe}> \\
\mathrm{Na}> \\
\mathrm{Si}>\mathrm{P} \\
>\mathrm{Sr}> \\
\mathrm{Pb}> \\
\mathrm{Zn}\end{array}$ \\
\hline 99 to 10 & $\begin{array}{c}\mathrm{Ni}>\mathrm{Mn} \\
>\mathrm{Ba}> \\
\mathrm{Zn}> \\
\mathrm{Cu}>\mathrm{Li} \\
>\mathrm{Cr}> \\
\mathrm{As}\end{array}$ & $\begin{array}{c}\mathrm{Ba}>\mathrm{Cu}> \\
\mathrm{Zn} \\
>\underset{\mathrm{Mn}>\mathrm{Ni}}{>\mathrm{Li}}\end{array}$ & $\begin{array}{c}\mathrm{B}>\mathrm{Mn}> \\
\quad \mathrm{Li} \\
>\mathrm{Ba}>\mathrm{Zn} \\
>\mathrm{Cu}>\mathrm{Ni}\end{array}$ & $\begin{array}{c}\mathrm{Zn}>\mathrm{B}> \\
\mathrm{Mn}>> \\
\mathrm{Ba}>\mathrm{Cu} \\
\quad>\mathrm{Li}\end{array}$ & $\begin{array}{c}\mathrm{Mn}>\mathrm{Zn} \\
>\mathrm{Ba}> \\
\mathrm{Cu}>\mathrm{Li} \\
>\mathrm{Pb}> \\
\mathrm{Cr}\end{array}$ & $\begin{array}{c}\mathrm{B}>\mathrm{Pb}> \\
\mathrm{Cu}>>\mathrm{Mn} \\
>\mathrm{Li}>\mathrm{Cr}\end{array}$ & $\begin{array}{l}\mathrm{Ba}>\mathrm{B} \\
>\mathrm{Mn} \\
>\underset{\mathrm{Cu}}{\mathrm{Li}}\end{array}$ \\
\hline 9.9 to 0.1 & Mo & $\begin{array}{c}\text { As }>\mathrm{Mo}> \\
\mathrm{Cr}\end{array}$ & $\begin{array}{c}\mathrm{Cr}>\mathrm{Mo}> \\
V\end{array}$ & $\mathrm{Cr}>\mathrm{Mo}$ & As $>$ Mo & & $\begin{array}{l}\mathrm{Cr}> \\
\mathrm{Mo}\end{array}$ \\
\hline $\begin{array}{c}\text { Not } \\
\text { Detected }\end{array}$ & $\begin{array}{l}\text { Cd, Co, } \\
\text { Pb, V }\end{array}$ & $\begin{array}{l}\text { Cd, Co, } \\
\mathrm{Pb}, \mathrm{V}\end{array}$ & $\begin{array}{l}\text { As, } \mathrm{Cd} \text {, } \\
\text { Co, } \mathrm{Pb}\end{array}$ & $\begin{array}{l}\text { As, Cd, } \\
\text { Co, } \\
\text { V }\end{array}$ & $\begin{array}{l}\text { Cd, Co, } \\
\text { V }\end{array}$ & $\begin{array}{c}\text { As, Cd, Co, } \\
\text { Mo, V }\end{array}$ & $\begin{array}{l}\text { As, } \\
\text { Cd, } \\
\text { Co, },\end{array}$ \\
\hline
\end{tabular}


Table 8. Upper-limit Values of Elements in Pinus spp. Samples by Origin

\begin{tabular}{|c|c|c|c|c|c|}
\hline $\begin{array}{l}\text { Range of } \\
\text { Upper-limit } \\
\text { Values } \\
(\mathrm{ppm}) \\
\end{array}$ & Chihuahua & Michoacán & Durango & Oaxaca & Nuevo León \\
\hline $\begin{array}{c}400,000 \text { to } \\
200,000\end{array}$ & K & & K & $\mathrm{K}$ & K \\
\hline \multicolumn{6}{|l|}{$\begin{array}{c}199,000 \text { to } \\
100,000\end{array}$} \\
\hline $\begin{array}{c}99,000 \text { to } \\
10,000\end{array}$ & $\mathrm{Ca}$ & $\mathrm{K}>\mathrm{Ca}>\mathrm{Al}$ & $\mathrm{Ca}$ & $\mathrm{Ca}>\mathrm{Al}$ & $\mathrm{Ca}>\mathrm{Al}$ \\
\hline $\begin{array}{c}9,900 \text { to } \\
1,000\end{array}$ & $\begin{array}{c}\mathrm{Al}>\mathrm{Mg}>\mathrm{Fe} \\
>\mathrm{Mn}> \\
\mathrm{Si}>\mathrm{P}>\mathrm{Na}\end{array}$ & $\begin{array}{c}\mathrm{Fe}>\mathrm{Mg}>\mathrm{P}> \\
\mathrm{Mn}>\mathrm{Si}\end{array}$ & $\begin{array}{c}\mathrm{Mg}>\mathrm{P}>\mathrm{Al}> \\
\mathrm{Mn}> \\
\mathrm{Fe}>\mathrm{Si}>> \\
\mathrm{Na}\end{array}$ & $\begin{array}{c}\mathrm{P}>\mathrm{Fe}>\mathrm{Mg} \\
>\mathrm{Mn}\end{array}$ & $\begin{array}{c}\mathrm{Fe}>\mathrm{Mg}>\mathrm{P} \\
>\mathrm{Mn}> \\
\mathrm{Si}>\mathrm{Na}\end{array}$ \\
\hline 990 to 100 & $\begin{aligned} \mathrm{Zn} & >\mathrm{Ba}>\mathrm{Ni} \\
& >\mathrm{Sr}> \\
\mathrm{Pb} & >\mathrm{B}>\mathrm{Cu}\end{aligned}$ & $\begin{array}{c}\mathrm{Zn}>\mathrm{Ba}>\mathrm{Na} \\
>\mathrm{Pb}> \\
\mathrm{Ni}>\mathrm{Sr}>\mathrm{B}> \\
\mathrm{Cu}\end{array}$ & $\begin{array}{c}\mathrm{Ba}>\mathrm{Zn}>\mathrm{Sr} \\
>\mathrm{Ni}> \\
\mathrm{B}>\mathrm{Cu}\end{array}$ & $\begin{array}{c}\mathrm{Ni}>\mathrm{Zn}>\mathrm{Na} \\
>\mathrm{B}>\mathrm{Si}> \\
\mathrm{Ba}>\mathrm{Cu}>\mathrm{Pb} \\
>\mathrm{Sr}\end{array}$ & $\begin{array}{c}\mathrm{Ba}>\mathrm{Zn}> \\
\mathrm{Sr}>\mathrm{Pb}> \\
\mathrm{Ni}>\mathrm{B}>\mathrm{Cu}\end{array}$ \\
\hline 99 to 10 & $\mathrm{Cr}>\mathrm{V}>\mathrm{Li}$ & $\mathrm{Cr}>\mathrm{V}$ & $\mathrm{Pb}$ & $\begin{array}{c}\mathrm{Cr}>\mathrm{V}_{\mathrm{Li}}>\mathrm{As}> \\
\end{array}$ & $\mathrm{Li}$ \\
\hline 9.9 to 0.1 & As $>$ Mo & $\mathrm{Li}>\mathrm{Mo}$ & $\begin{array}{c}\mathrm{Li}>\mathrm{Cr}>\mathrm{V}> \\
\text { As }\end{array}$ & Mo & $\mathrm{V}>\mathrm{As}>\mathrm{Cr}$ \\
\hline $\begin{array}{c}\text { Not } \\
\text { Detected }\end{array}$ & Cd, Co & As, Cd, Co & Cd, Co, Mo & Cd, Co & Cd, Co, Mo \\
\hline
\end{tabular}

Table 9. Upper-limit Values of Elements in Quercus spp. Samples and Citric Biomass

\begin{tabular}{|c|c|c|c|c|c|}
\hline \multirow{2}{*}{$\begin{array}{l}\text { Range of } \\
\text { Upper-limit } \\
\text { Values } \\
\text { (ppm) }\end{array}$} & \multirow[b]{2}{*}{ Quercus spp } & \multicolumn{4}{|c|}{ Citric Samples } \\
\hline & & $\begin{array}{c}\text { Lime } \\
\text { Branches }\end{array}$ & Lime Leaves & $\begin{array}{l}\text { Orangee } \\
\text { Branches }\end{array}$ & $\begin{array}{l}\text { Lemon } \\
\text { Peels }\end{array}$ \\
\hline $\begin{array}{c}400,000 \text { to } \\
200,000\end{array}$ & K & K & K & $\mathrm{K}$ & K \\
\hline \multicolumn{6}{|l|}{$\begin{array}{c}199,000 \text { to } \\
100,000\end{array}$} \\
\hline $\begin{array}{c}99,000 \text { to } \\
10,000\end{array}$ & $\mathrm{Ca}$ & $\mathrm{P}>\mathrm{Ca}$ & $\mathrm{Ca}>\mathrm{P}$ & $\mathrm{Ca}$ & $\mathrm{Ca}>\mathrm{P}$ \\
\hline $\begin{array}{c}9,900 \text { to } \\
1,000\end{array}$ & $\begin{aligned} \mathrm{P} & >\mathrm{Mg}>\mathrm{Mn} \\
& >\mathrm{Al}> \\
\mathrm{Fe} & >\mathrm{Si}>\mathrm{Na}\end{aligned}$ & $\mathrm{Mg}>\mathrm{Sr}>\mathrm{Na}$ & $\begin{array}{c}\mathrm{Mg}>\mathrm{Ba}>\mathrm{Na} \\
>\mathrm{Sr}>\mathrm{Si}\end{array}$ & $\mathrm{P}>\mathrm{Mg}$ & $\begin{array}{c}\mathrm{Mg}>\mathrm{Fe}> \\
\mathrm{Al}>\mathrm{Mn} \\
\mathrm{Na}>\mathrm{Ba}\end{array}$ \\
\hline 990 to 100 & $\begin{array}{c}\mathrm{Ba}>\mathrm{Sr}>\mathrm{Ni}> \\
\mathrm{B}>\mathrm{Zn}\end{array}$ & $\begin{array}{c}\mathrm{Ba}>\mathrm{Fe}>\mathrm{Mn} \\
>\mathrm{Al}> \\
\mathrm{B}>\mathrm{Zn}\end{array}$ & $\begin{array}{c}\mathrm{Mn}>\mathrm{Fe}>\mathrm{Al} \\
>\mathrm{B}\end{array}$ & $\begin{array}{c}\mathrm{Na}>\mathrm{Fe}>\mathrm{Sr} \\
>\mathrm{Ba} \\
\mathrm{Al}>\mathrm{B}\end{array}$ & $\begin{aligned} \mathrm{Sr} & >\mathrm{Zn}>\mathrm{Ni} \\
& >\mathrm{Si}> \\
\mathrm{B} & >\mathrm{Pb}>\mathrm{Cu}\end{aligned}$ \\
\hline $99-10$ & $\mathrm{~Pb}>\mathrm{Cu}$ & $\begin{aligned} \mathrm{Cu}> & \mathrm{Ni}>\mathrm{Pb} \\
& >\mathrm{Li}\end{aligned}$ & $\begin{array}{c}\mathrm{Zn}>\mathrm{Cu}>\mathrm{Li} \\
>\mathrm{Ni}\end{array}$ & $\begin{array}{c}\mathrm{Mn}>\mathrm{Zn}>\mathrm{Si} \\
>\mathrm{Cu} \\
\mathrm{Li}>\mathrm{Ni}\end{array}$ & \\
\hline $9.9-0.1$ & $\mathrm{Li}>\mathrm{Cr}>\mathrm{V}$ & & $\mathrm{Cr}$ & $\mathrm{V}>\mathrm{Pb}>\mathrm{Cr}$ & $\begin{array}{l}\mathrm{V}>\mathrm{Cr}>\mathrm{Li} \\
>\mathrm{Mo}>\mathrm{Co}\end{array}$ \\
\hline $\begin{array}{c}\text { Not } \\
\text { Detected }\end{array}$ & $\begin{array}{c}\text { As, Cd, Co, } \\
\text { Mo }\end{array}$ & $\begin{array}{l}\text { As, Cd, Co, } \\
\text { Cr, Mo, Si, V }\end{array}$ & $\begin{array}{l}\text { As, Cd, Co, } \\
\text { Mo, Pb, V }\end{array}$ & $\begin{array}{c}\text { As, Cd, Co, } \\
\text { Mo, }\end{array}$ & As, Cd \\
\hline
\end{tabular}


The typical values of the minor chemical elements in European woods in $\mathrm{mg} / \mathrm{kg}$, both for conifers and broadleaved trees, are as follows: $\mathrm{Zn}(10), \mathrm{Cu}(2), \mathrm{Pb}(2), \mathrm{V}(<2)$, $\mathrm{Cr}$ (1), Ni (0.5), Cd (0.1), As (<0.1), and Hg (0.02) (UNE-EN 14961-1 2011). This scheme was not observed in the Mexican biomass samples studied here.

\section{CONCLUSIONS}

1. The particle size distribution of the biomass of the sawdust residues is adequate for the production of densified biofuels. The dimensions and proportions found here largely avoid grinding and energy consumption for drying.

2. The biomass with the greatest possibilities for making densified biofuels of better quality is the group of pine woods because they have low mineral content, low nitrogen content, and high calorific value.

3. The densification of pine biomass will be able to generate class A1, A2, and B pellets. Given that forests are dominated by coniferous woods, it is a good opportunity to generate densified biofuels of the best quality in terms of ash content as it is common that the percentage of these does not exceed $1.0 \%$ in the Pinus genus.

4. The biomass of the tropical wood group has a high content of inorganic material, which is a limitation for making densified biofuels or to meet demanding quality standards. However, in certain localities with abundant raw materials of this type, solid biofuels may be generated that do not demand high quality but may generate heat in some devices.

5. Citrus residues had a high content of ash and nitrogen, so they would be suitable for the production of densified biofuels with certain criteria of lower quality, according to the classification within internationally established standards.

6. The major chemical elements were in the range of 990 to $100 \mathrm{ppm}$ and higher in tropical woods and citrus residues, while from 9,900 to $990 \mathrm{ppm}$ in pine and oak woods.

7. Minor chemical elements were in the range of 99 to $10 \mathrm{ppm}$ in tropical woods, while in pine woods, oak woods, and citrus residues were in the range of 990 to $100 \mathrm{ppm}$ and less.

\section{ACKNOWLEDGMENTS}

The authors are grateful for the support of the Project Fondo Sectorial FSESENER-CONACYT (CEMIE-Bio) Grant No. 246911. The authors also thank the people who helped in the contact to collect the material, as well as all the companies and/or "ejidos" that donated the biomass samples.

This article is dedicated to Roberto de Alba Flores on the occasion of his retirement as professor at the Universidad Michoacana de San Nicolás de Hidalgo. 


\section{REFERENCES CITED}

Arcibar-Orozco, J. A., Josue, D.-B., Ríos Hurtado, J. C., and Rangel Méndez, J. R. (2014). "Influence of iron content, surface area and charge distribution in the arsenic removal by activated carbons," Chem. Eng. J. 249, 201-209. DOI: 10.1016/j.cej.2014.03.096

Arias-Chalico, T. (2018). "Situación actual y escenarios para el desarrollo de biocombustibles sólidos en México hacia 2024 y 2030 [Current situation and scenarios for the development of solid biofuels in Mexico around 2024 and 2030]," Red Mexicana de Bioenergia, (http://rembio.org.mx/situacion-actual-y-escenariospara-el-desarrollo-de-biocombustibles-solidos-en-mexico-hacia-2024-y-2030-teresitaarias-chalico-m-sc/), Accessed 25 May 2020.

ASTM E872-82 (2013). "Standard test method for volatile matter in the analysis of particulate wood fuels," ASTM International, West Conshohocken, PA, USA.

Ávila-Calderón, L. E. A., and Rutiaga-Quiñones, J. G. (2015). "Wood chemical components of three species from a medium deciduous forest," Wood Res. 60(3), 479-486.

Bernabé-Santiago, R., Ávila-Calderón, L. E. A., and Rutiaga Quiñones, J. G. (2013). "Componentes químicos de la madera de cinco especies de pino del municipio de Morelia, Michoacán [Chemical components of the wood of five pine species from the municipality of Morelia, Michoacán]," Madera. Bosques 19(2), 21-35. DOI: 10.21829/myb.2013.192338

Camps, M. M., and Marcos, M. F. (2008). Los Biocombustibles ( $2^{\text {nd }}$ Ed.), Mundi-Prensa, Libros, Spain.

Cárdenas-Gutiérrez, M. A., Herrera-Bucio, F. E. P.-B. R., López-Albarrán, P., RutiagaQuiñones, J. G., Correa-Méndez, F., and Herrera-Bucio, R. (2018). "Chemical components of the branches of six hardwood species," Wood Res. 63(5), 795-808.

Carrillo-Parra, A., Ngangyo-Heya, M., Colín-Urieta, S., Foroughbakhch, R., RutiagaQuiñones, J. G., and Correa-Méndez, F. (2018). "Physical, mechanical and energy characterization of wood pellets obtained from three common tropical species," PeerJ. 4(6), e5504. DOI: 10.7717/peerj.5504

CONAFOR (2017). "Perspectivas de la industria forestal en México [Prospects for the forest industry in Mexico]," Comisión Nacional Forestal [National Forestry Commission], (http://www.conafor.gob.mx/innovacion_forestal/?edicion=74), Accessed 29 May 2020.

Cordero, T., Márquez, F., Rodríguez-Marisol, J., and Rodríguez, J. J. (2001). "Predicting heating value of lignocellulosics and carbonaceous materials from proximate analysis," Fuel 80(11), 1567-1571. DOI: 10.1016/S0016-2361(01)00034-5

Correa-Méndez, F., Carrillo-Parra, A., Rutiaga-Quiñones, J. G., González-Rodríguez, H., Jurado-Ybarra, E., and Garza-Ocañas, F. (2013). "Humedad, ceniza e inorgánicos en corteza industrial de tres pinos para bioenergía [Moisture, ash and inorganic in industrial bark of three pines for bioenergy]," Revista Forestal Baracoa 32(2), 77-83.

Correa-Méndez, F., Carrillo-Parra, A., Rutiaga-Quiñones, J. G., Márquez-Montesino, F., González-Rodríguez, H., Jurado-Ybarra, E., and Garza-Ocañas, F. (2014).

"Contenido de humedad y sustancias inorgánicas en subproductos maderables de pino para su uso en pélets y briquetas [Moisture and inorganic substance content in pine timber products for use in pellets and briquettes]," Revista Chapingo Serie Ciencias Forestales y del Ambiente 20(1), 77-88. DOI: 10.5154/r.rchscfa.2013.04.012 
Demirbaş, A. (1997). "Calculation of higher heating values of biomass fuels," Fuel 76(5), 431-434. DOI: 10.1016/S0016-2361(97)85520-2

Escorsim, A. M., Da Rocha, G., Vargas, J. V. C., Mariano, A. B., Ramos, L. P., Corazza, M. L., and Cordeiro, C. S. (2018). "Extraction of Acutodesmus obliquus lipids using a mixture of etanol and hexane as solvent," Biomass. Bioenerg. 108, 470-478. DOI: 10.1016/j.biombioe.2017.10.035

Fengel, D., and Wegener, G. (1983). Wood-Chemistry, Ultrastructure, Reactions, Walter de Gruyter, Berlin, Germany.

Fidan, M. S., and Ertaş, M. (2020). "Biobased rigid polyurethane foam prepared from apricot stone shell-based polyol for thermal insulation application, Part 1: Synthesis, chemical, and physical properties," BioResources 15(3), 6061-6079. DOI: 10.15376/biores.15.3.6061-6079.

García, C. A., Riegelhaupt, E., and Masera, O. (2016). "Introducción [Introduction]," in: Estado del Arte de la Bioenergía en México, Red Temática de Bioenergía (RTB) del CONACYT., C.A. García Bustamante and O. Masera (eds.), Imagia Comunicación, Guadalajara, México, pp. 9-14.

García, R., Pizarro, C., Lavín, A. G., and Bueno, J. L. (2012). “Characterization of Spanish biomass wastes for energy use,” Bioresource Technol. 103(1), 249-258. DOI: 10.1016/j.biortech.2011.10.004

Ghetti, P., Ricca, L., and Angelini, L. (1996). "Thermal analysis of biomass and corresponding pyrolysis products," Fuel 75(5), 565-573. DOI: 10.1016/00162361(95)00296-0

Grover, P., and Mishra, S. (1996). Biomass Briquetting: Technology and Practices (Field Document 46), Regional Wood Energy Development Programme in Asia, Food and Agriculture Organization of the United Nations, Bangkok, Thailand.

Herrera-Fernández, A. C., Carrillo-Parra, A., Pedraza-Bucio, F. E., Correa-Méndez, F., Herrera-Bucio, R., López-Albarrán, P., and Rutiaga-Quiñones, J. G. (2017). "Densidad, composición química y poder calorífico de la madera de tres especies de encino (Quercus candicans, Q. laurina y Q. rugosa) [Density, chemical composition and calorific value of three oak wood species (Quercus candicans, $Q$. laurina, and $Q$. rugosa)]," Ciencia Nicolaita 72, 136-154.

ISO 17225-2 (2014). "Solid biofuels - Fuel specifications and classes," International Organization for Standardization, Geneva, Switzerland.

Karinkanta, P., Ämmälä, A., Illikainen, M., and Niinimäki, J. (2018). "Fine grinding of wood - Overview from wood breakage to applications," Biomass. Bioenerg. 113(6), 31-44. DOI: 10.1016/j.biombioe.2018.03.007

Lyngfelt, A., Åmand, L.-E., Gustavsson, L., and Leckner, B. (1996). "Methods for reducing the emission of nitrous oxide from fluidized bed combustion," Energ. Convers. Manage. 37(6-8), 1297-1302. DOI: 10.1016/0196-8904(95)00336-3

MacBain, R. (1966). "Pelleting animal feed," Regional Feed School Presentation. American Feed Manufacturing Association, Arlington, VA, USA, pp. 1-28.

Martínez-Pérez, R., Pedraza-Bucio, F. E., Orihuela-Equihua, R., López-Albarrán, P., and Rutiaga-Quiñones, J. G. (2015). "Calorific value and inorganic material of ten Mexican wood species," Wood Res. 60(2), 281-292.

Mitchual, S. J., Frimpong-Mensah, K., and Darkwa, N. A. (2014). "Evaluation of fuel properties of six tropical hardwood timber species for briquettes," J. Sustain. Bioenergy Syst. 4(1), 1-9. DOI: 10.4236/jsbs.2014.41001 
Ngangyo-Heya, M., Foroughbahchk, R., Carrillo-Parra, A., Rutiaga-Quiñones, J. G., Zelinski, V., and Pintor-Ibarra, L. F. (2016). "Calorific value and chemical composition of five semi-arid Mexican tree species," Forests 7(3), Article number 58. DOI: 10.3390/f7030058

Núñez-Retana, V. D., Escobedo-Bretado, M. A., Quiñones-Reveles, M., Rui-Aquino, F., and Carrillo-Parra, A. (2019). "Efecto del contenido de humedad sobre pélets de aserrín de madera de Pinus spp [Effect of moisture content on Pinus spp wood sawdust pellets]," Revista Mexicana de Agroecosistemas 6(2), 136-144.

Nussbaumer, T. (2002). "Combustion and co-combustion of biomass: Fundamentals, technologies, and primary measures for emission reduction," in: Proceedings of the 12th European Biomass Conference Volume I, Florence, Italy, pp. 31-37.

Obernberger, I., and Thek, G. (2004). "Physical characterisation and chemical composition of densified biomass fuels with regard to their combustion behaviour," Biomass. Bioenerg. 27(6), 653-669. DOI: 10.1016/j.biombioe.2003.07.006

Obernberger, I., Brunner, T., and Bärnthaler, G. (2006). "Chemical properties of solid biofuels_-significance and impact," Biomass. Bioenerg. 30(11), 973-982. DOI: 10.1016/j.biombioe.2006.06.011

Obernberger, I., and Thek, G. (2010). The Pellet Handbook, Earthscan, London, England. ÖNORM M 7135 (2000). "Compressed wood or compressed bark in natural state-pellets and briquettes, requirements and test specifications," Österreichisches Normungsinstitut [Austrian Standards Institute], Vienna, Austria.

Ortiz, L., Tejada, A., Vázquez, A., and Piñeiro Veiras, G. (2003). “Aprovechamiento de la biomasa forestal producida por la cadena monte-industria, Parte III: Producción de elementos densificados [Use of forest biomass produced by the forest-industry chain, Part III: Production of densified elements]," Revista del Centro de Innovación y Servicios Tecnológicos de la Madera de Galicia CIS-Madera 11, 17-32.

Payne, J. (1978). “Improving quality of pellet feeds," Mill. Feed Fetil. 162, 34-41.

Pintor-Ibarra, L. F., Carrillo-Parra, A., Herrera-Bucio, R., López-Albarrán, P., and Rutiaga-Quiñones, J. G. (2017). "Physical and chemical properties of timber byproducts from Pinus leiophylla, P. montezumae and $P$. pseudostrobus for a bioenergetic use," Wood Res. 62(6), 849-861.

REMBIO (2011). "La Bioenergía en México: Situación actual y perspectivas [Bioenergy in Mexico: Current situation and prospects]," Red Mexicana de Bioenergía [Mexican Bioenergy Network], (http://rembio.org.mx/wp-content/uploads/2014/12/CT4.pdf), Accessed 25 May 2020.

Riegelhaupt, E. (2016). "Biocombustibles sólidos [Solid biofuels]," in: Estado del Arte de la Bioenergía en México. Red Temática de Bioenergía (RTB) del CONACYT., C. A. García Bustamante, and O. Masera (eds.), Imagia Comunicación, Guadalajara, México, pp. 23-33.

Rodríguez-Jiménez, S., Duarte-Aranda, S., and Canché-Escamilla, G. (2019). "Chemical composition and thermal properties of tropical wood from the Yucatán dry forests," BioResources 14(2), 2651-2666. DOI: 10.15376/biores.14.2.2651-2666

Ruiz-Aquino, F., Ruiz-Ángel, S., Feria-Reyes, R., Santiago-García, W., and RutiagaQuiñones, J. G. (2019). "Wood chemical composition of five tree species from Oaxaca, Mexico," BioResources 14(4), 9826-9839. DOI: 10.15376/biores.14.4.98269839 
Rutiaga-Quiñones, J. G., and García-Díaz, J. (1999). "Elementos químicos en las cenizas del duramen de dos maderas tropicales [Chemical elements in heartwood ash of two tropical woods]," Ciencia Forestal en México 24(86), 109-115.

SENER (2019). "Balance Nacional de Energía 2018 [National Energy Balance 2018]," Secretaría de Energía [Secretary of Energy], (https://www.gob.mx/cms/uploads/attachment/file/528054/Balance_Nacional_de_Ene rg_a_2018.pdf), Accessed 28 May 2020.

Sheng, C., and Azevedo, J. L. T. (2005). "Estimating the higher heating value of biomass fuels from basic analysis data," Biomass. Bioenerg. 28(5), 499-507. DOI: 10.1016/j.biombioe.2004.11.008

Spinelli, R., Nati, C., Sozzi, L., Magagnotti, N., and Picchi, G. (2011). "Physical characterization of commercial woodchips on the Italian energy market," Fuel 90(6), 2198-2202. DOI: 10.1016/j.fuel.2011.02.011

Tauro, R., Ghilardi, A., García, C. A., and Masera, O. (2016). "Recursos biomásicos [Biomass resources]," in: Estado del Arte de la Bioenergía en México. Red Temática de Bioenergía (RTB) del CONACYT., C. A. García Bustamante, and O. Masera (eds.), Guadalajara, México, pp. 15-22.

Telmo, C., Lousada, J., and Moreira, N. (2010). "Proximate analysis, backwards stepwise regression between gross calorific value, ultimate and chemical analysis of wood," Bioresource Technol. 101(11), 3808-3815. DOI: 10.1016/j.biortech.2010.01.021

Turner, R. (1995). "Bottomline in feed processing: Achieving optimum pellet quality," Feed Management 46, 30-33.

UNE-CEN/TS 15104 EX (2008). "Determinación del contenido de carbono, hidrógeno y nitrógeno. Métodos instrumentales [Determination of the content of carbon, hydrogen and nitrogen. Instrumental methods]," AENOR, Madrid, Spain.

UNE-EN 14774-1 (2010). "Determinación del contenido de humedad, Método de secado en estufa. Parte 1: Humedad total [Determination of moisture content. Method of oven drying. Part 1: Total humidity]," AENOR, Madrid, Spain.

UNE-EN 14775 (2010). "Método para la determinación del contenido en cenizas [Method for the ash content determination]," AENOR, Madrid, Spain.

UNE-EN 14961-1 (2011). "Especificaciones y clases de combustibles. Parte 1: Requisitos generales [Fuel specifications and classes. Part 1: General requirements]," AENOR, Madrid, Spain.

UNE-EN 15149-2 (2011). "Determinación de la distribución de tamaño de partícula. Parte 2: Método del tamíz vibrante con abertura de malla inferior o igual a $3.15 \mathrm{~mm}$ [Determination of the particle size distribution. Part 2: Vibrating screen method with mesh opening less than or equal to $3.15 \mathrm{~mm}$ ]," AENOR, Madrid, Spain.

Van Lith, S. C., Alonso, V., Jensen, P. A., Frandsen, F. J., and Glarborg, P. (2006). "Release to the gas phase of inorganic elements during wood combustion. Part 1: Development and evaluation of quantification methods," Energ. Fuel. 20(3), 964978. DOI: 10.1021/ef050131r

Vassilev, S. V., Baxter, D., Andersen, L. K., and Vassileva, C. G. (2010). “An overview of the chemical composition of biomass," Fuel 89(5), 913-933. DOI:

10.1016/j.fuel.2009.10.022

Velázquez Martí, B. (2018). Aprovechamiento de la Biomasa para uso Energético [Exploitation of Biomass for Energy Use] (2nd Ed.), Editorial Reverté, Barcelona, Spain. 
Villaseñor-Araiza, J. C., and Rutiaga-Quiñones, J. G. (2000). "La madera de Casuarina equisetifolia L., química e índices de calidad de pulpa [Casuarina equisetifolia L. wood, chemical and pulp quality indices]," Madera. Bosques 6(1), 29-40. DOI: 10.21829/myb.2000.611340

Werkelin, J., Skrifvars, B.-J., and Hupa, M. (2005). "Ash-forming elements in four Scandinavian wood species. Part 1: Summer harvest," Biomass. Bioenerg. 29(6), 451456. DOI: 10.1016/j.biombioe.2005.06.005

Zavala, D. Z., and Cortés, R. H. (2000). “Análisis del rendimiento y utilidad del proceso de aserrío de trocería de pino [Analysis of the performance and utility of the pine log sawing process]," Madera. Bosques 6(2), 41-55. DOI: 10.21829/myb.2000.621374

Article submitted: June 17, 2020; Peer review completed: September 12, 2020; Revised version received and accepted: September 16, 2020; Published: September 23, 2020.

DOI: $10.15376 /$ biores.15.4.8529-8553 